Ocean-colour Chl a trends in European

Seas

\title{
Chl $a$ trends in European seas estimated using ocean-colour products
}

G. Coppini ${ }^{1}$, V. Lyubarstev ${ }^{2}$, N. Pinardi $^{3}$, S. Colella ${ }^{4}$, R. Santoleri ${ }^{4}$, and T. Christiansen ${ }^{5}$

${ }^{1}$ Istituto Nazionale di Geofisica e Vulcanologia, Sezione di Bologna, Italy

${ }^{2}$ Centro Euro Mediterraneo per i Cambiamenti Climatici, Italy

${ }^{3}$ Centro Interdipartimentale di Ricerca per le Scienze Ambientali, Università of Bologna, Ravenna, Italy

${ }^{4}$ Consiglio Nazionale delle Ricerche, Istituto per le Scienze dell'Atmosfera e del Clima, Rome, Italy

${ }^{5}$ European Environment Agency, Copenhagen, Denmark

Received: 1 March 2012 - Accepted: 6 March 2012 - Published: 30 March 2012

Correspondence to: G. Coppini (giovanni.coppini@bo.ingv.it)

Published by Copernicus Publications on behalf of the European Geosciences Union.
Title Page

Abstract

Introduction

Conclusions

\section{References}

Tables

Figures

14

4

Back

Full Screen / Esc

Printer-friendly Version

Interactive Discussion

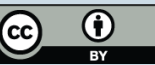




\section{Abstract}

Ocean-colour remote-sensing products have been used to estimate Chl a trends in European seas. This work aims to develop a new indicator based on ocean-colour data for the European Environment Agency (EEA). The new indicator, called CSI023(+), 5 produced from satellite ocean-colour products from the MyOcean Marine Core Service (www.myocean.eu) has been defined and calculated. CSI023 (+) is intended to complement the EEA CSI023 (Core Set of Indicators n.23) indicator for eutrophication, which is based on chlorophyll a (Chl a) in-situ observations. Validation of ocean-colour products has been carried out through comparison with observations of the Eionet EEA database, and we believe that such validation should continue in the future, perhaps with a dedicated data-collection exercise. Ocean colour has a much higher spatial and temporal resolution than the in-situ observations. The ocean-colour observations, however, are based on indirect measurements of the optical properties of the ocean, which are transformed to Chl a using an appropriate algorithm. This algorithm can either be a global algorithm that reproduces the average global Chl a concentrations well or one that is adjusted to specific regional conditions. In our analysis we have used both global and regional (adjusted to specific regional Mediterranean conditions) ocean-colour products, but the results highlight the fact that regional products produced with regional algorithms are recommended for the future.

This work proposes a methodology for analysing trends comparable to the method EEA uses for its CSI23 indicator. Analysis has revealed the potential of ocean colour as a CSI023(+) indicator: large-scale, and in some cases even local-scale, changes appear to be captured by the satellite images even though in general the ocean-colour products underestimate the Chl a values. CSI023(+) shows, in the period 1998-2009, decreasing Chl a concentrations throughout the Black Sea, in the Eastern Mediterranean, in the southern part of the Western Mediterranean, in the English Channel and in the north part of the North Sea, whereas large areas with increasing trends are observed in the Bay of Biscay, in the North-East Atlantic regions of Ireland and the UK, in
OSD

$9,1481-1518,2012$

Ocean-colour Chl a trends in European Seas

G. Coppini et al.

\section{Title Page}


the northern part of the North Sea, in the Kattegat and in the Baltic. Specific analysis has been performed in the Mediterranean and the Black Sea: we first defined Chl a areas and then calculated the CSI023(+) for each of the Chl a areas. This last analysis reveals that about $80 \%$ of $\mathrm{Chl} a$ areas do not show significant trends; increasing signif5 icant $\mathrm{Chl}$ a trends were detected in $3 \mathrm{Chl} \mathrm{a}$ areas in the Black Sea and $32 \mathrm{Chl}$ a areas in the Mediterranean. Decreasing significant trends were detected in $6 \mathrm{Chl}$ a areas in the Mediterranean and $2 \mathrm{Chl}$ a areas in the Black Sea.

\section{Introduction}

A recent review (Ferreira et al., 2011) has presented an overview of eutrophication 10 indicators for assessing environmental status within the European Marine Strategy Framework Directive (MSFD). Ferreira et al., 2011 arrived at the following definition of eutrophication as the basis for interpreting the MSFD descriptor: "Eutrophication is a process driven by enrichment of water by nutrients, especially compounds of nitrogen and/or phosphorus, leading to: increased growth, primary production and biomass of 15 algae; changes in the balance of organisms; and water quality degradation. The consequences of eutrophication are undesirable if they appreciably degrade ecosystem health and/or the sustainable provision of goods and services". Among the biological indicators proposed to describe the status of eutrophication the report indicates $\mathrm{Chl}$ a, which will increase due to increased nutrient availability. There is extensive literature

on the use of phytoplankton as an indicator of eutrophication in inshore and offshore waters. All methods include $\mathrm{Chl}$ a as an indicator of phytoplankton biomass, though the metrics differ. It is clear that $\mathrm{Chl} a$ alone is not enough to estimate eutrophication processes and provide a complete picture of eutrophic conditions. Chl $a$ is one of the variable to be monitored and other characteristics should also be included in addition to $\mathrm{Chl} a$, such as changes in community composition, occurrence of nuisance and toxic species resulting from changes in nutrient ratios, and increased duration and frequency of blooms resulting from increases in nutrient loads (Ferreira et al., 2011).

\section{OSD}

$9,1481-1518,2012$

Ocean-colour Chl a trends in European Seas

G. Coppini et al.

\section{Title Page}


Eutrophication in marine waters has been a management concern in Europe over recent decades. Legislative frameworks have been set up, including the Water Framework Directive (WFD) and the MSFD on transitional and marine waters. The WFD requires the achievement of good ecological status or good ecological potential of tran5 sitional and coastal waters across the EU by 2015, while the MSFD's aim is to achieve good environmental status of the EU's marine waters by 2020. Moreover, several other EU Directives are aimed at reducing nutrient loads and impacts. These include the Nitrates Directive (91/676/EEC) aimed at reducing nitrate pollution from agricultural land; the Urban Waste Water Treatment Directive (91/271/EEC) aimed at reducing pollution 10 from sewage treatment works and certain industries; the Integrated Pollution Prevention and Control Directive (96/61/EEC) aimed at controlling and preventing pollution of water from industry. Measures also arise from a number of other international initiatives and policies including the UN Global Programme of Action for the Protection of the Marine Environment against Land-Based Activities; the 1975 Mediterranean Action 15 Plan (MAP); the 1992 Helsinki Convention (HELCOM) on the Protection of the Marine Environment of the Baltic Sea Area; the 1998 OSPAR Convention for the Protection of the Marine Environment of the North East Atlantic and the 1994 Convention on the Protection of the Black Sea Against Pollution (Bucharest Convention).

The EEA uses an indicator based on in-situ Chl a trends to monitor eutrophication 20 in the European seas; this is referred to as CSI023 (Chlorophyll in transitional, coastal and marine waters) in the EEA system. For a complete overview of the indicator, please refer to the following web site: http://www.eea.europa.eu/data-and-maps/indicators/ chlorophyll-in-transitional-coastal-and/chlorophyll-in-transitional-coastal-and-2 The objective of the CSI023 indicator is to demonstrate the effects of policy measures taken to reduce loading of nitrogen and phosphates from rivers that affect primary production biomass in the coastal zones. CSI023 is calculated from $\mathrm{Chl}$ a in-situ profiles estimated by fluorimeter and averaged in the summer ${ }^{1}$ and in the first $10 \mathrm{~m}$

\footnotetext{
${ }^{1}$ Summer is defined as the months from June to September for stations north of 59 degrees in the Baltic Sea (Gulf of Bothnia and Gulf of Finland) and from May to September for all other stations.
}

\section{OSD}

$9,1481-1518,2012$

Ocean-colour Chl a trends in European Seas

G. Coppini et al.

\section{Title Page}

\section{Full Screen / Esc}

Printer-friendly Version

Interactive Discussion 
of depth. The CSI023 is defined as the significant increasing or decreasing temporal trend for each station.

The last EEA assessment was performed in July 2011, and its results are presented in terms of concentration of Chl $a$ in the European seas and CSI023 from 1985 to 2009.

5 The in-situ $\mathrm{Chl}$ a estimates are provided to the EEA through the Eionet network (http://www.eionet.europa.eu/). Measurements using fluorimeters are given at selected coastal stations, providing an accurate measure of $\mathrm{Chl} a$, although with a low temporal and spatial resolution. A second problem related to in situ Chl $a$ is poor coverage, especially in Southern European seas, and we have therefore identified the challenge 10 of integrating the in-situ dataset with ocean-colour products to complement the former and provide EEA and Member States with valuable information for eutrophication assessment.

Measurements using satellite radiometers of water-leaving radiance in the visible range (ocean colour) can today be used to determine $\mathrm{Chl}$ a concentration, which is an indicator of algal photosynthetic activity and thus related to phytoplankton biomass. Chl a can now be estimated from ocean-colour data at daily frequencies and $250 \mathrm{~m}$ horizontal resolutions.

Ocean-colour satellite products are now available from SeaWiFS, MERIS-Envisat and MODIS-AQUA sensors. The future Sentinel-3 GMES satellite will also have an ocean-colour sensor ensuring continuous monitoring for the period 2015-2030. The first ocean-colour sensor, CZCS, was in operation from approximately 1980 to 1986 , but the second, SeaWiFS, only started in 1997.

Estimation of $\mathrm{Chl}$ a from ocean colour is an integral value over the e-folding scale of light in water. The ocean-colour transformation algorithms have been calibrated with in-situ data at a global scale for the GSM product (Maritorena et al., 2010; Maritorena and Siegela, 2005) and with in-situ datasets acquired in the Mediterranean Sea for the MEDOC4 product (Volpe et al., 2007).
OSD

$9,1481-1518,2012$

Ocean-colour Chl a trends in European Seas

G. Coppini et al.

\section{Title Page}

Abstract

\section{Full Screen / Esc}

Printer-friendly Version

Interactive Discussion 
The optical properties of oceanic waters can be classed into Case 1 or Case 2 waters (Morel and Prieur, 1977; Gordon and Morel, 1983; Prieur and Sathyendranath, 1981). By definition, Case 1 waters are those in which phytoplankton (with their accompanying and co-varying retinue of other material of biological origin) are the principal agents 5 responsible for variations in optical properties of the water. On the other hand, Case 2 waters are influenced not only by phytoplankton and related biological particles, but also by inorganic particulate and dissolved material. The water-leaving radiance of shelf and coastal waters is significantly influenced by suspended inorganic particulate and dissolved material, making the retrieval of Chl a from a unique algorithm, from 10 the open ocean to the coasts, less accurate. In conclusion, Case 1 optical properties can be modelled as a function of Chlorophyll-a concentration only, while the simplicity of single-variable models has to be abandoned when dealing with Case 2 waters. At least three relevant quantities (phytoplankton, suspended inorganic materials and yellow substances, and perhaps even bottom reflectance) can vary independently of each other, and specific algorithms related to optical water properties should be used. In shelf and coastal waters, Case 2 waters, suspended inorganic matter and yellow substances (coloured organic dissolved matter, CDOM) significantly influence the waterleaving radiance, making the retrieval of $\mathrm{Chl}$ a from satellites less accurate. However, the CDOM information is important and should be used in the future as a new indicator of river influence in coastal areas. In our analysis we used global and regional (adjusted to specific regional Mediterranean conditions) ocean-colour products, both developed for Case 1 waters because only these type of products were available.

The analyses of derived apparent optical properties temporal variability in European seas is conducted in Vantrepotte and Melin 2010 on the SeaWiFS dataset (19972007) and the Chl a trends presented in our paper are consistent with the products such as reflectance band ratio trends as presented in Vantrepotte and Melin 2010. Moreover, inter-annual variations in the SeaWiFS global Chl a concentration (19972007) are presented in Vantrepotte and Melin 2011 for the Global Ocean, but a direct comparison with our results cannot be presented because Vantrepotte and Melin 2011
OSD

9, 1481-1518, 2012

Ocean-colour Chl a trends in European Seas

G. Coppini et al.

Title Page

Abstract Introduction

Conclusions

Tables References Figures

14

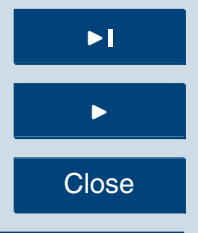

Full Screen / Esc

Printer-friendly Version

Interactive Discussion

1486 
presents the results for the Global Ocean and study the full year trends, whereas we focus only on the summer period for consistency with existing EEA CSI023 and we focussed specifically on European Seas.

This paper aims to develop a methodology to complement the EEA CSI023 indicator 5 with observations based on ocean colour from space. This is developed in this paper, and named CSI023(+).

The purpose of the paper is:

1. Analyse the ocean colour trends in European seas;

2. Compare ocean-colour Chl a data and trends with in-situ ones;

3. Present the trends of $\mathrm{Chl}$ a as $\mathrm{CSIO23} \mathrm{(+)} \mathrm{in} \mathrm{the} \mathrm{European} \mathrm{seas} \mathrm{for} \mathrm{the} \mathrm{period}$ 1998-2009.

The paper is organized as follows: Section 2 describes the satellite data sources, it defines the indicator, the $\mathrm{Chl}$ a areas concept and the methods; Sect. 3 the results; Sect. 4 the validation of datasets; Sect. 5 concludes the paper.

\section{Data and methods}

\subsection{Satellite data sources}

In this work we used two different ocean-colour datasets (Table 1). The "Global Ocean GSM - MyOcean" Chl a dataset, developed within the framework of GlobColour (www. globcolour.info) and regularly produced and distributed by the Global Monitoring for 20 Environment and Security (GMES) MyOcean project, and "Med Regional SeaWiFS MyOcean and CNR" that is produced by MyOcean and the Consiglio Nazionale delle Ricerche (CNR), Istituto per le Scienze dell'Atmosfera e del Clima (ISAC), Italy.

The first dataset, Global Ocean GSM - MyOcean, is obtained using GSM algorithm (Maritorena et al., 2002; Maritorena and Siegel, 2005). One of the major characteristics
OSD

$9,1481-1518,2012$

Ocean-colour Chl a trends in European Seas

G. Coppini et al.

\section{Title Page}

Abstract

\section{Full Screen / Esc}

Printer-friendly Version

Interactive Discussion 
of the product is that it combines normalized water-leaving radiances from different satellite-sensor datasets (Maritorena et al., 2010). Over each particular grid point of a geographical grid common to SeaWiFS, AQUA and MERIS the radiance of each sensor is combined and it is used to invert a semi-analytical model of Chl a (Maritorena et al., 5 2002). This product has been available since September 1997 and the time-series is constituted of daily products delivered by MyOcean with a one-month delay. In this work we have performed analysis of ocean-colour data for the period 1998-2009.

The second dataset, Med Regional SeaWiFS - MyOcean and CNR, is the Mediterranean product produced with the regional algorithm MedOC4 (Volpe et al., 2007) from 10 the SeaWiFS sensor only. The MedOC4 algorithm has been validated with a large insitu bio-optical dataset for the Mediterranean area, and its performance has been compared with global algorithms such as OC4v4 for SeaWiFS, and the results show that MedOC4 is the best algorithm for satellite chlorophyll estimates in the Mediterranean (Volpe et al., 2007). This product was accessed in two consistent time series: the first 15 covered the period January 1998-December 2004 and is delivered by MyOcean and is constituted by daily fields of Chl a, while the second covers the period 2004-2007 and is delivered by CNR and is constituted by monthly mean of Chl a. The SeaWiFS regional product for the period 2004-2007 was still covered by a commercial licence and was not distributed by MyOcean at the time we accessed the data. The MedOC4 algorithm is tested and valid up to values of $10 \mathrm{mg} \mathrm{m}^{-3}$ of Chl $a$ and therefore we have decided to mask the $\mathrm{Chl}$ a data that were higher than this value.

It is important to underline that the Mediterranean and global GSM products are calibrated for open ocean waters and not specifically for coastal waters, and a lower performance in the coastal zone is therefore to be expected.

\subsection{CSI023 (+) indicator definition}

CSI023 (+) is computed from MyOcean ocean-colour gridded data as a temporal trend at each grid point starting from 1998. CSI023 $(+)$ thus consists of significant Chl a trends normalized by the Chl a Standard Deviation (STD), and the units of CSI023 (+)
OSD

$9,1481-1518,2012$

Ocean-colour Chl a trends in European Seas

G. Coppini et al.

Title Page

Abstract Introduction

Conclusions

Tables References

Figures

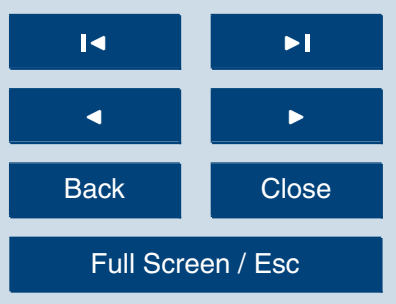

Printer-friendly Version

Interactive Discussion 
are $\left(\mathrm{mg} \mathrm{m}^{-3}\left(\mathrm{mg} \mathrm{m}^{-3}\right)^{-1} \mathrm{yr}^{-1}\right)$. In other words, CSI023 (+) represents Chl a annual rate of change with respect to the Chl a variability (STD) in the specific period.

CSI023 (+) is presented in the following two ways:

- "CSI023 (+) Pan-European trend indicator" calculated in European seas ${ }^{2}$ based on a global ocean-colour dataset (Global Ocean GSM - MyOcean ${ }^{3}$ product) from MyOcean at a resolution of approximately $4 \mathrm{~km}$

- "CSI023 (+) Chl a areas ${ }^{4}$ trend indicator" calculated in Southern European seas (the Mediterranean Sea and the Black Sea) based on a regional ocean-colour dataset (Med Regional SeaWiFS - MyOcean and $\mathrm{CNR}^{5}$ product) from MyOcean and CNR at a resolution of $1 \mathrm{~km}$.

\subsection{Statistical analysis}

This section describes the method used to calculate the trend and climatology (Fig. 1 left panel) from ocean-colour data. For each grid point a yearly time series of summer mean Chl a concentration was calculated for the period 1998-2009 (12 points maximum, some summer values can be missing at some grid points).

Trend values $\left.\left(\left(\mathrm{mg} \mathrm{m}^{-3}\right) \mathrm{yr}^{-1}\right)\right)$ are estimated using Sen's slope method (Sen, 1968; Gilbert, 1987; El-Shaarawi et al., 2001) for each grid point Chl a time series.

For each grid point Sen's method calculates the slope of all data value pairs:

$Q_{m}=\frac{X_{i}-X_{j}}{i-j}$ For all $i$ and $j$ where $i>j$

\footnotetext{
${ }^{2}$ In each figure of the paper the Sea of Azov have been masked because it is very shallow (maximum $15 \mathrm{~m}$ depth) and ocean-colour products would be strongly affected by bottom reflectance; the White Sea has been masked because it was out of our domain of interest.

${ }^{3}$ The Global Ocean GSM - MyOcean product is described in Sect. n 2.1.

${ }^{4} \mathrm{Chl}$ a areas are defined in Sect, 2.4 .

${ }^{5}$ The Med Regional SeaWiFS - MyOcean and CNR dataset is described in Sect. 2.1.
}

OSD

9, 1481-1518, 2012

Ocean-colour Chl a trends in European Seas

G. Coppini et al.

\section{Title Page}
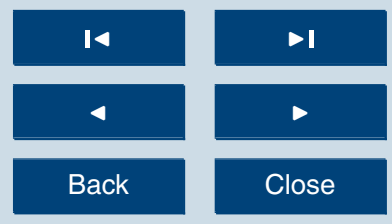

Back

Close

\section{Full Screen / Esc}

Printer-friendly Version

Interactive Discussion 
Where:

$X_{i}$ and $X_{j}$ are the summer mean Chl a concentration for years $i$ and $j$;

OSD

$Q_{m}$ is the linear slope between $X_{i}$ and $X_{j}$ summer values;

9, 1481-1518, 2012

5

$m$ is the index of slope estimates.

If there are $n$ summer values $X_{i}$ in the time series we get as many as $M=\frac{n *(n-1)}{2}$ slope estimates $Q_{m}$ and $m=1 \ldots M$.

Sen's estimator of slope is the median of these $M$ values of $Q$. For each grid point the $M$ values of $Q$ are ranked from the smallest to the largest and Sen's estimator is:

SLOPE $=Q_{[(M+1) / 2]}$ if $M$ is odd;

SLOPE $=\left(Q_{[M / 2]}+Q_{[(M+2) / 2]}\right) / 2$ if $M$ is even;

A Mann-Kendal statistics check (Salmi et al., 2002; Gilbert, 1987) is applied to each

$15 \mathrm{Chl}$ a grid point to identify the statistical significant SLOPE values at a $95 \%$ confidence level.

Chl a standard deviation values are calculated for each grid point where SLOPE is significant as follows:

$\operatorname{STD}=\sqrt{\frac{1}{n} \sum^{N}\left(X_{i}-\bar{x}\right)^{2}}$

20 Where:

$n$ is the number of summers values at this grid point;

$X_{i}$ is the summer mean $\mathrm{Chl}$ a concentration at year $\mathrm{i}$;

Ocean-colour Chl a trends in European

Seas

G. Coppini et al.

Title Page

Abstract

Introduction

Conclusions

References

Tables

Figures

14

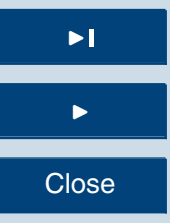

Back

Close

Full Screen / Esc

Printer-friendly Version

Interactive Discussion 
$\bar{x}$ is the multi-year summer mean Chl a concentration.

SLOPE is then normalized by the Chl a STD values of each grid point so that CSI023 $(+)$ is then calculated as:

$5 \operatorname{CSI023}(+)=\frac{\text { SLOPE }}{\text { STD }}$

The units of CSI023 $(+)$ are $\left(\mathrm{mg} \mathrm{m}^{-3}\left(\mathrm{mg} \mathrm{m}^{-3}\right)^{-1} \mathrm{yr}^{-1}\right)$ representing annual change of $\mathrm{Chl}$ a over the specified period with respect to the $\mathrm{Chl}$ a variability (STD).

Once CSI023 (+) values have been calculated at each ocean-colour data grid point they are presented in two different ways:

10 (1) In a map over the European seas for values above the $95 \%$ confidence level (Fig. 2 left panel).

(2) Histograms of percentages of positive, negative and not significant values of CSI023 (+) in the Mediterranean and Black Sea Chl a areas (Fig. 3). For this paper only 2 graphs are shown.

\section{$15 \quad 2.4$ Chl $a$ areas description}

In the Mediterranean Sea, Black Sea and Sea of Marmara, where a regional oceancolour product at high spatial resolution was available, a special application of CSI023 (+) was performed for the period 1998-2007. This application uses the concept of "Chl a areas", defined on the basis of river basins and political borders, where Chl a 20 trends are calculated. This method makes use of the high spatial resolution of the colour images and thus produces a more robust trend estimate than the pan-European trend indicator.

$\mathrm{Chl} a$ areas were defined in the Mediterranean (66 Chl a areas), the Black Sea $(5 \mathrm{Chl} a$ areas) and Sea of Marmara $(1 \mathrm{Chl} a$ area) using information on the River 25 Basin Districts (RBDs), and political borders when RBDs were not defined. Moreover,

OSD

$9,1481-1518,2012$

Ocean-colour Chl a trends in European Seas

G. Coppini et al.

\section{Title Page}

Abstract Introduction

Conclusions References

Tables Figures

14

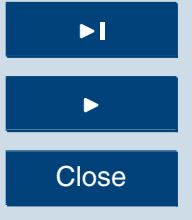

Back

Close

\section{Full Screen / Esc}

Printer-friendly Version

Interactive Discussion 
$18^{6}$ open-ocean sub-basins were identified in the Mediterranean and used to design the $\mathrm{Chl} a$ areas. Within each $\mathrm{Chl}$ a area two sub-areas are defined: a coastal one (IN), from the coast to a depth of 30 metres and an off-shore one (OFF), from a depth of 30 to 200 metres. A name composed of 3 parts is associated with each single $\mathrm{Chl} a$ area 5 as following: 1) name of the RBD or name of the country; 2) name of the sub-basin; 3) 'IN' if it is the inshore part of the Chl a area or "OFF" if it is the offshore part of the Chl a area.

For example, the off-shore part of the Maltese Chl a area in the Strait of Sicily will be named "Malta-SSI-OFF".

\section{Results}

The mean summer (May-September) spatial distribution of Chl a concentration $\left(\mathrm{mg} \mathrm{m}^{-3}\right)$ in coastal European seas for the period 1998-2009 calculated from both the Global Ocean GSM - MyOcean ocean-colour product (Fig. 1 left panel) and insitu data (Fig. 1 right panel) is presented. CSI023(+) is presented in the two formats 15 defined: (a) CSI023(+) pan-European trend indicator and (b) CSI023(+) Chl a areas trend indicator in the Southern European seas. Paragraphs 3.1 to 3.3 present the abovementioned results.

\subsection{Spatial distribution of $\mathrm{Chl}$ a concentration in coastal European seas (Chl a summer climatology)}

20 The European seas summer Chl a mean $\left(\mathrm{mg} \mathrm{m}^{-3}\right)$ over the period 1998-2009 (Fig. 1 left panel) shows highest values in the Baltic Sea, in the southern North Sea and the

\footnotetext{
${ }^{6}$ North Adriatic Sea (NAD), South Adriatic Sea (SAD), Algerian Sea (ALG), Alboran Sea (ALS), Algero-Provençal Basin (APB), Gulf of Gabès (GGA), Gulf of Lion (GLI), Iberian Sea (Balearic Sea) (IBS), North lonian Sea (NIO), South Ionian Sea (SIO), North Levantine Basin (NLB), South Levantine Basin (SLB), Ligurian Sea (LGS), Strait of Sicily (SSI), North Tyrrhenian Sea (NTY), South Tyrrhenian Sea (STY).
}

\section{OSD}

$9,1481-1518,2012$

Ocean-colour Chl a trends in European Seas

G. Coppini et al.

\section{Title Page}

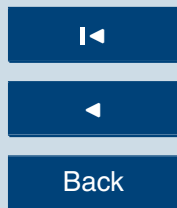

\section{Full Screen / Esc}

Printer-friendly Version

Interactive Discussion 
Western Black Sea. The lowest values are reached in the Mediterranean Sea openocean areas. The Irish Sea, Bay of Biscay and Portuguese Atlantic areas also show high Chl a values, although these are lower than the Baltic and North Sea. In the Mediterranean the low $\mathrm{Chl}$ a values show a negative east-west gradient that is very 5 well known for this area (Siokou-Frangou et al., 2010; D'Ortenzio and d'Alcalà 2009). The Black Sea shows highest values in the north-western part of the basin (Danube area). The in-situ climatology (Fig. 1 right panel) reveals the sampling problem of the insitu dataset. The two climatologies show similar values in most of the Baltic Sea with the exceptions of the Gulf of Finland and Gulf of Riga where ocean-colour products o underestimate in-situ values. In the southern part of the North Sea in-situ and ocean colour show similar mean values, although there is still an evident underestimation of the values by the ocean colour. In the northern part of the Adriatic Sea, the in-situ and ocean-colour products show similar values, while in the southern areas of the Adriatic ocean colour once again underestimates the in-situ values. In the Ligurian Sea too the ocean-colour products underestimate in-situ observations, as they also do in the Tyrrhenian Sea.

\section{$3.2 \operatorname{CSIO23(+)}$}

Two different ways of presenting CSI023 (+) have been defined in Paragraph 2.2:

1. Pan-European trends of Chl a based on the Global Ocean GSM - MyOcean ocean-colour dataset for the period 1998-2009. The methodology used to calculate pan-European trends is described in Paragraph 2.3).

2. Mediterranean and Black Sea trends for each Chl a area for the period 19982007, based on high resolution (1 km) Med Regional SeaWiFS - MyOcean and CNR product. Chl $\boldsymbol{a}$ areas are described in Paragraph 2.4 The methodology used to calculate pan-European trends is described in Paragraph 2.3.
OSD

$9,1481-1518,2012$

Ocean-colour Chl a trends in European Seas

G. Coppini et al.

\section{Title Page}

Abstract

Introduction

Conclusions

Tables

References

Figures

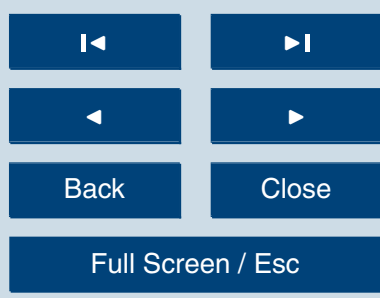

Printer-friendly Version

Interactive Discussion 
Below we present CSI023(+) analysis in terms of pan-European trends and Chl a area trends.

\subsubsection{CSI023(+) pan-European trends:}

CSI023(+) over the period 1998-2009 is presented in Fig. 2 (left panel). CSI023

$5(+)$ shows areas with decreasing $\mathrm{Chl}$ a concentrations in the Black Sea, the Eastern Mediterranean, the southern part of the Western Mediterranean and the English Channel, whereas areas with increasing trends are observed in the northern lonian Sea, the off-shore area of the Bay of Biscay, the North-East Atlantic, the North Sea, the Kattegat and the Baltic. Only points above the $95 \%$ confidence level are presented, and white areas in the map therefore correspond to grid points not showing any significant trend.

The Chl a standard deviation over the period 1998-2009 presented in Fig. 2 (right panel) shows that natural variability is high in the Baltic, the North Sea, the NorthEast Atlantic shelf areas and the northern regions of the Mediterranean and the Black Sea. Chl a natural variability appears low in the Mediterranean, with a minimum in the 15 Eastern Mediterranean basin.

\subsubsection{CSI023(+) Chl a area trends}

In the Mediterranean, Black Sea and Sea of Marmara, when a regional ocean-colour product at high spatial resolution was available a special application of CSI023 (+) was performed for the period 1998-2007. CSI023 (+) is calculated for each Chl a area and the way of presenting results for this special application of CSI023 (+) is based upon the classic $\mathrm{CSI023}$ indicator mapping showing the percentage of decreasing, increasing and no-trend stations (Fig. 3). We show the number of colour- image grid points with decreasing, increasing and null trends. In this paper we discuss the results of all the Chl a areas, but we selected only some of them (Black Sea Chl a areas and $2514 \mathrm{Chl}$ a areas in the Mediterranean), which that are presented in Fig. 3. The CSI023 (+) Chl a areas indicator for the Southern European seas shows that about $80 \%$ of
OSD

$9,1481-1518,2012$

Ocean-colour Chl a trends in European Seas

G. Coppini et al.

\section{Title Page}

Abstract

\section{Full Screen / Esc}

Printer-friendly Version

Interactive Discussion 
Chl $a$ areas do not show significant trends. Increasing Chl a trends (higher than $10 \%$ of the grid points in each area) were detected in following areas:

- The Ukraine and Georgia areas (Georgia-BS-IN and -OFF and Ukraine-BS-IN);

- The Turkish Aegean area Turkey (AEG-OFF);

- The Maltese area in the Strait of Sicily Strait (Malta-SSI-IN);

- The Greek areas (Crete-AEG-IN and -OFF, Epirus-NIO-IN and -OFF, Western-Sterea Ellada-NIO-IN and -OFF, Northern-Peloponnese-SIO-IN and OFF, Western-Peloponnese-AEG-IN and -OFF, Eastern-Peloponnese-AEG-OFF, Attica-AEG-IN and Eastern-Sterea-Ellada-AEG-IN);

- The Egyptian area (Egypt-SLB-IN -OFF);

- The Tunisian areas (Tunisia-GGA-IN and Tunisia-SSI-IN and -OFF);

- The Italian Southern Apennines area (South.-Apennines-SAD-IN) and North Adriatic Sea area (Po-NAD-IN);

- The Croatian area in the North Adriatic Sea (Croatia-NAD-IN);

- The Albanian area (Albania-SAD-IN);

- The Italian areas in the Ligurian Sea (Serchio-LGS-IN and North.-ApenninesLGS-2-IN);

- The Italian Strait of Sicily area (Sicily-SSI-IN);

- The Balearic islands area (Balearic-APB-IN and Júcar-IBS-IN and -OFF areas);

- The Alboran Sea Spanish south-western areas (Cuencas-Med.-Andaluzas-IN and -OFF, Júcar-ALS-IN);

OSD

9, 1481-1518, 2012

Ocean-colour $\mathrm{Chl} \mathrm{a}$ trends in European

Seas

G. Coppini et al.

\section{Title Page}

Abstract

Introduction

Conclusions

References

Tables

Figures

14

DI

4

Back

Close

Full Screen / Esc

Printer-friendly Version

Interactive Discussion 
- The Moroccan area (Morocco-ALS-OFF).

Decreasing significant $\mathrm{Chl}$ a trends (higher than $10 \%$ of the pixels) were detected in the following areas:

- The Slovenian area (Vodno-NAD);

- The Turkish areas in the Black Sea (Turkey-BS-In and -OFF) and Northern Levantine Basin (Turkey-NLB-IN and -OFF)

- The Syrian area (Syria-SLB-IN);

- The Maltese areas (Malta-SSI-OFF and Malta-SIO).

\section{Validation against in-situ data}

10 The validation of the ocean-colour products used to calculated CSI023 (+) is presented in Table 2. The method consists of comparing the ocean-colour products with in-situ values from the EEA-Eionet databank. When using the Global Ocean GSM - MyOcean at a spatial resolution of 1/24 deg the in-situ Eionet observations are averaged to $1 / 24 \times 1 / 24$ deg. Global Ocean GSM - MyOcean data are compared with corre15 sponding in-situ data collected on the same day. The number of corresponding in-situ and ocean-colour daily values for the Global Ocean GSM - MyOcean product in the summer period is 5470 . Corresponding daily in-situ and ocean-colour data are averaged in the summer and then compared.

When using the Med Regional SeaWiFS - MyOcean and CNR, validation was done 20 using monthly $\mathrm{Chl}$ a values, since only monthly ocean-colour values were available for the period 2004-2007. When using the Med Regional SeaWiFS - MyOcean and CNR, in order to perform the comparison between point in-situ observations and monthly ocean-colour data we decided to search, within the selected month, for in-situ data in a surrounding area of $5 \mathrm{~km} \times 5 \mathrm{~km}$ around each single satellite observation; then

OSD

9, 1481-1518, 2012

Ocean-colour Chl a trends in European Seas

G. Coppini et al.

Title Page

Abstract Introduction

Conclusions

Tables References

Figures
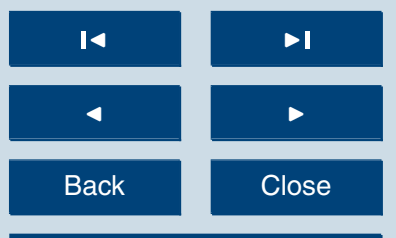

Full Screen / Esc

Printer-friendly Version

Interactive Discussion 
the identified in-situ observations were averaged to $5 \mathrm{~km} \times 5 \mathrm{~km}$ bins. The number of corresponding in-situ and ocean-colour monthly values for the Med Regional SeaWiFS - MyOcean and CNR product is 7822.

The data treatment of the Global Ocean GSM - MyOcean and Med Regional SeaW5 iFS - MyOcean and CNR differs because of the time and spatial resolution differences of the two datasets.

In some locations the ocean-colour products are differ greatly from the in-situ observations; one reason could be that in some cases in situ data quality could be low (i.e. problem with calibration of instruments is expected due to the large number of data 10 providers; some geographical coordinates of the single profiles were provided without rounded at the minutes value) and this information is not provided with the Eionet datasets (i.e. data are not flagged for different quality levels). Moreover as explained in paragraph 2.1 ocean colour data used in this paper are based upon open ocean algorithms and therefore they are not as accurate as needed in the very coastal zone where part of the in situ data have been collected. We therefore decided to eliminate the data from both in-situ and ocean-colour datasets when the difference among them was more than five times. These values are eliminated from the dataset that is then used for the CSI023 (+) and climatology calculations and the validation. This filtering is possible because data are abundant enough and because the validation can only be done if the values are compatible. After this filtering, 4584 corresponding data remained for Global Ocean GSM - MyOcean. In the case of Med Regional SeaWiFS - MyOcean and CNR, dataset masking was applied to monthly values and after this filtering the remaining data were 6156.

Different validation tests were performed, and the results are presented in Fig. 4 25 to Fig. 15. Tests 1, 2 and 3 were performed using Global Ocean GSM - MyOcean products, while Test 4 was performed using Med Regional SeaWiFS - MyOcean and CNR products. The correlations for Tests 1 and 4 were performed taking the logarithm on a decimal basis of the $\mathrm{Chl}$ a values.
OSD

$9,1481-1518,2012$

Ocean-colour Chl a trends in European Seas

G. Coppini et al.

\section{Title Page}

Abstract Introduction

Conclusions

Tables References

\section{Figures}

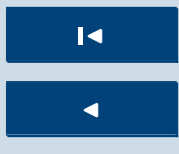

Back

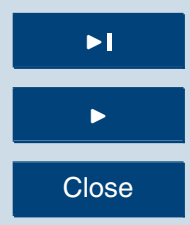

Full Screen / Esc

Printer-friendly Version

Interactive Discussion 
The correlation between in-situ data and Global Ocean GSM - MyOcean ocean colour Chl a concentration (Test 1$)$ is high $\left(R^{2}=0.8\right)$ when analysis is carried out using all the data covering the entire European seas domain (Fig. 4), at the basin scales as expected correlation values are lower, for the Mediterranean (Fig. 5), North Sea (Fig. 6) 5 and North-East Atlantic (Fig. 8) $\left(R^{2}\right.$ is equal to 0.6), while for the Baltic Sea (Fig. 7) the correlation drops noticeably $\left(R^{2}=0.3\right)$.

Figure (9) presents results of Test 2 where summer 2005 mean ocean-colour Chl a concentration values (Global Ocean GSM - MyOcean) are compared to in-situ data in European seas: values agree qualitatively in Italian seas and the Kattegat and Skager10 rak areas, while in the Baltic the ocean-colour product underestimates in-situ observations.

Test 3 evaluates the summer mean of $\mathrm{Chl}$ a concentration and the linear trend in the European seas. European seas $\mathrm{Chl}$ a summer mean concentration values estimated by Global Ocean GSM - MyOcean underestimate the in-situ measurements (Fig. 10), 15 and linear trends are similar. Figure 11 shows similar concentrations for in-situ and ocean-colour observations in the Mediterranean, where no reliable trend is detected. Figures 12 and 13 show that $\mathrm{Chl}$ a trend estimated by ocean colour is similar to the in-situ one in the Baltic and North Sea, but the Chl a summer mean concentration estimated by Global Ocean GSM - MyOcean underestimates the in-situ measurements. In the North-East Atlantic (Fig. 14) ocean colour is comparable with in-situ data for the period 1999-2001 and trends are positive but with different amplitudes.

The comparison of Med Regional SeaWiFS - MyOcean and CNR with in-situ data (Test 4$)$ in the Mediterranean Sea also shows a good correlation $\left(R^{2}=0.7\right)$ (Fig. 15), which is higher than that observed with the Global Ocean GSM - MyOcean data (Fig. 4; $\left.25 R^{2}=0.6\right)$. A regional product thus seems to be preferable respect to Global Ocean GSM - MyOcean in comparison with in-situ data.
OSD

$9,1481-1518,2012$

Ocean-colour Chl a trends in European Seas

G. Coppini et al.

\section{Title Page}

Abstract Introduction

Conclusions

Tables References Figures
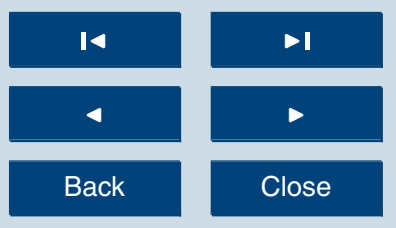

Full Screen / Esc

Printer-friendly Version

Interactive Discussion 


\section{Conclusions}

The CSIO23 (+) indicator based on ocean colour products has been developed to contribute to the state-of-the-environment assessment and, in particular, the monitoring of eutrophication trends. The comparison of $\mathrm{Chl}$ a concentrations and trends estimated 5 through remote sensing with in-situ ones has been performed. The comparison presented shows that the global ocean-colour algorithm seems to underestimate $\mathrm{Chl}$ a concentration (Fig. 1). The CSIO23 (+) indicator shows the capability of detecting significant negative and positive terms for $\mathrm{Chl}$ a trends in European seas, thereby allowing us to complement the in-situ CSIO23 covering only part of the European coastal areas.

10 The CSIO23(+) indicator also shows a large area with decreasing Chlorophyll a concentrations in the Black Sea, the Mediterranean, the English Channel and the northern part of the North Sea; whereas a large area with increasing trends is observed in the Bay of Biscay and the Baltic. Trends estimated by ocean colour products show similar slope and sign if compared with trends estimated by in-situ data (Fig. 10 to Fig. 14). 15 Moreover, the Med Regional SeaWiFS - MyOcean and CNR regional dataset used in the Mediterranean Sea seems to show a good comparison with in-situ data, but further investigations need to be performed to compare the trends at the level of $\mathrm{Chl}$ a areas as well. Chl $a$ area analysis offers the possibility of synthesizing CSIO23(+) information and focuses attention on coastal areas. The analysis has also revealed the need for regional ocean-colour products to be available to develop support of the EEA indicator, as well as the fact that there is potential in a long-term trend analysis based on ocean colour, as large-scale, and in some cases even regional-scale, changes appear to be captured by the satellite images. It is clear, however, that in order to build confidence in this analysis it needs to be based on the best possible regional products. As the MyOcean products do not consists of complete reprocessed data, it is planned that as soon as new regional datasets are available they will be used to calculate CSIO23 (+).

\section{OSD}

$9,1481-1518,2012$

Ocean-colour Chl a trends in European Seas

G. Coppini et al.

\section{Title Page}

\section{Full Screen / Esc}

Printer-friendly Version

Interactive Discussion 
Although Global Ocean GSM - MyOcean and Med Regional SeaWiFS - MyOcean and CNR (for the period 1998-2004) were available as daily products, not all the information from ocean colour has been used yet because CSI023 (+) uses summer mean values in analogy with classical in-situ CSI023. However, for the future we plan 5 to use full daily satellite $\mathrm{Chl}$ a estimate resolution to evaluate changes in the statistical significance of the results.

Acknowledgements. Work of this paper has been carried out within the framework of the European Topic Centre on Inland, Coastal and Marine Waters (ETC/ICM) (http://icm.eionet.europa. $\mathrm{eu} /$ ), the European Topic Centre on Water (ETC/W) and MyOcean (www.myocean.eu.org) 10 projects.

\section{References}

D'Ortenzio, F. and Ribera d'Alcalà, M.: On the trophic regimes of the Mediterranean Sea: a satellite analysis, Biogeosciences, 6, 139-148, doi:10.5194/bg-6-139-2009, 2009.

Ferreira, J. G., Andersen, J. H., Borja, A., Bricker, S. B., Camp, J., Cardoso da Silva, M., Garcés, E., Heiskanen, A.-S., Humborg, C., Ignatiades, L., Lancelot, C., Menesguen, A., Tett, P., Hoepffner, N., and Claussen, U.: Overview of eutrophication indicators to assess environmental status within the European Marine Strategy Framework Directive, Estuarine, Coastal and Shelf Science, 93, 117-131, 2011.

Gordon, H. and Morel, A.: Remote assessment of ocean color for interpretation of satellite 20 visible imagery: A review, Springer-Verlag (Lecture Notes on Coastal and Estuarine Studies, Volume 4), 1983, 118 pp., 1983.

Lavender, S. J., Pinkerton, M. H., Froidefond, J.-M., Morales, J., Aiken, J., and Moore, G. F.: SeaWiFS validation in European coastal waters using optical and bio-geochemical measurements, INT. J. Remote Sensing, 10-20 April, 2004, 25, 7-8, 1481-1488, 2004.

25 Maritorena, S. and Siegela, D. A.: Consistent merging of satellite ocean color data sets using a bio-optical model, Remote Sens. Environ., 94, 429-440, 2005.

Maritorena, S., Siegel, D. A., and Peterson, A.: Optimization of a semi-analytical ocean color model for global scale applications, Appl. Optics, 41, 2705-2714, 2002.

\section{OSD}

$9,1481-1518,2012$

Ocean-colour Chl a trends in European Seas

G. Coppini et al.

\section{Title Page}

Abstract

Introduction

Conclusions

Tables

References

Figures

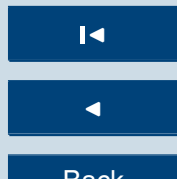

$\Delta$

$\triangleright$

Back

Close

Full Screen / Esc

Printer-friendly Version

Interactive Discussion 
Maritorena, S., Fanton d'Andonb, O. H., Manginb, A., and Siegela, D. A.: Merged satellite ocean color data products using a bio-optical model: Characteristics, benefits and issues, Remote Sens. Environ., 114, 16 August 2010, 1791-1804, 2010.

Morel, A. and Prieur, L.: Analysis of variations in ocean-colour, Limnol. Oceanogr., 22, 709722, 1977.

O'Reilly, J. E., Maritorena, S., O'Brien, M. C., Siegel, D. A., Toole, D., Menzies, D., Smith, R. C., Mueller, J. L., Mitchell, B. G., Kahru, M., Chavez, F. P., Strutton, P., Cota, G. F., Hooker, S. B., McClainD, C. R., Carder, K. L., Muller-Karger, F., Harding, L., Magnuson, A., Phinney, D., Moore, G. F., Aiken, J., Arrigo, K. R., Letelier, R., and Culver, M.: Ocean color chlorophyll a algorithms for SeaWiFS, OC2 and OC4: version 4, in: SeaWiFS Post Launch Calibration and Validation Analyses, edited by: Hooker, S. B. and Firestone, E. R., (Greenbelt, MD: NASA Goddard Space Flight Center), 11, 9-23, 2000.

Prieur, L. and Sathyendranath, S.: An optical classification of coastal and oceanic waters based on the specific spectral absorption curves of phytoplankton pigments, dissolved organic matter and other particulate materials, Limnol. Oceanogr., 26, 671-689, 1981.

Salmi T., Määttä, A., Anttila, P., Ruoho-Airola, T., Amnell, T.: Detecting Trends of annual values of Atmospheric pollutants by the Mann-Kendall test and Sen's slope estimates - The excel template application Makesens (2002), IImanlaadun julkaisuja Publikationer om luftkvalitet Publications on air quality No. 31, IImatieteen laitos, Meteorologiska Institutet, Finnish Meteorological Institute, Helsinki, 2002.

Sen, P. K.: Estimates of the regression coefficient based on Kendall's tau, J. Am. Stat. Assoc., 63, 1379-1389, 1968.

Siokou-Frangou, I., Christaki, U., Mazzocchi, M. G., Montresor, M., d'Alcalà, M. R., Vaque, D., and Zingone, A.: Plankton in the open Mediterranean Sea: a review. Biogeosciences, 7, 1543-1586, 2010, http://www.biogeosciences.net/7/1543/2010/.

Vantrepotte, V. and Melin, F.: Temporal variability in SeaWiFS derived apparent optical properties in European seas, Cont. Shelf Res., 30, 319-334, 2010.

Vantrepotte, V. and Melin, F.: Inter-annual variations in the SeaWiFS global chlorophyll a concentration (1997-2007), Deep-Sea Res. Pt. I, 58, 429-441, 2011.

Volpe, G., Santoleri, R., Vellucci, V., Ribera d'Alcalà, M., Marullo, S., D'Ortenzio, F.: The color of the Mediterranean Sea: Global versus regional bio-optical algorithms evaluation and implication for satellite chlorophyll estimates, Remote Sens. Environ., 107, 625-638, 2007.

\section{OSD}

$9,1481-1518,2012$

Ocean-colour Chl a trends in European Seas

G. Coppini et al.

\section{Title Page}

Abstract

\section{Full Screen / Esc}

Printer-friendly Version

Interactive Discussion 


\section{OSD}

$9,1481-1518,2012$

Ocean-colour Chl a trends in European

Seas

G. Coppini et al.

Table 1. Overview of ocean-colour data products used in the calculation of CSI023 (+).

\begin{tabular}{|c|c|c|c|c|c|}
\hline Dataset name & Domain & $\begin{array}{l}\text { Spatial } \\
\text { resolution }\end{array}$ & $\begin{array}{l}\text { Time frame } \\
\text { and resolution }\end{array}$ & $\begin{array}{l}\text { Algorith } \\
\mathrm{m} / \text { merging method }\end{array}$ & Provider \\
\hline $\begin{array}{l}\text { Global Ocean GSM - } \\
\text { MyOcean }\end{array}$ & Global Ocean & $\begin{array}{l}1 / 24^{\circ}=2.5 \prime \\
(2.5 \prime \text { latitude }=4630 \mathrm{~m} ; \\
2.5 \prime \text { longitude }=3274 \mathrm{~m} \\
\text { at Lat } 45 \mathrm{~N})\end{array}$ & $\begin{array}{l}\text { 09/1997- } \\
\text { 09/2009 } \\
\text { daily }\end{array}$ & GSM & MyOcean \\
\hline $\begin{array}{l}\text { Med Regional SeaWiFS - } \\
\text { MyOcean and CNR }\end{array}$ & $\begin{array}{l}\text { Mediterranean Sea } \\
\text { and Black Sea }\end{array}$ & $\begin{array}{l}\text { Approximately } 1 \times 1 \mathrm{~km} \\
\text { (Latitude step: } 1131 \mathrm{~m} \text {, } \\
\text { Longitude step: } \\
45 \mathrm{~N}->1006 \mathrm{~m} \\
30 \mathrm{~N}->1245 \mathrm{~m} \text { ) }\end{array}$ & $\begin{array}{l}\text { 05/1998- } \\
09 / 2004 \\
\text { daily } \\
\text { 10/2004- } \\
\text { 09/2007 monthly }\end{array}$ & $\begin{array}{l}\text { Mediterranean - } \\
\text { MEDOC4 } \\
\text { and CNR for the } \\
\text { period 2004-2007 }\end{array}$ & $\begin{array}{l}\text { MyOcean for the } \\
\text { period 1998-2004 }\end{array}$ \\
\hline
\end{tabular}


Table 2. Validation table: the left-hand column lists the variable validated; the central column describes the type of spatial and/or temporal aggregation performed; the right-hand column describes the validation results.

\section{Test \# and variables compared}

$\begin{array}{ll}\text { Test } 1 & \text { Summer mean and } \\ \text { Chl a concentration } & \text { European seas }\end{array}$

Chl a concentration European seas

Test 2

Chl a concentration

Test 3

Chl a concentration

Test 4

Chl a concentration
Summer mean

for 2005

Basin and summer mean and European seas

\section{Results of comparison}

High correlation $\left(R^{2}=0.8\right)$ if the analysis is performed for all the available stations in the European seas (Fig. 4). Comparison is still favourable $\left(R^{2}=0.6\right)$ for the Mediterranean (Fig. 5), North Sea (Fig. 6) and

North-East Atlantic (Fig. 8). Low correlation $\left(R^{2}=0.3\right)$ is found when the analysis is performed for the Baltic Sea stations (Fig. 7).

Relevant similarities in Italian seas, the Kattegat and the Skagerrak. In the Baltic Sea the ocean-colour product underestimates the in-situ observations. (Fig. 9)

Summer mean of $\mathrm{Chl}$ a concentrations estimated by ocean colour underestimate the in-situ measurements when analysis is performed at the level of European I (Figure 10) and trends are similar. In the Mediterranean Sea

(Fig. 11) Chl a values are similar and no reliable trend is estimates the in-situ measurements, ocean colour and in situ

trends are similar and positive. In the North Sea (Fig.13) ocean colour underestimates in-situ $\mathrm{Chl}$ a concentration values; ocean colour and in-situ trends are similar and positive. In

the North-East Atlantic (Fig. 14), ocean colour is comparable with in-situ data for the period 1999-2001 and trends are positive but with different amplitude.

Summer average concentration for Chl a areas
Summer mean ocean colour $\mathrm{Chl}$ a concentration values are similar to in-situ ones $\left(R^{2}=0.7\right)($ Fig. 15). detected. In the Baltic Sea (Fig. 12) ocean colour under-
OSD

9, 1481-1518, 2012

Ocean-colour Chl a trends in European Seas

\section{G. Coppini et al.}

\section{Title Page}

Abstract

Introduction

Conclusions

References

Tables

Figures

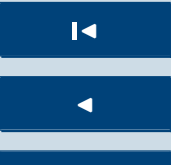

Back

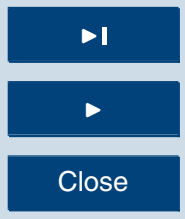

Full Screen / Esc

Printer-friendly Version

Interactive Discussion 

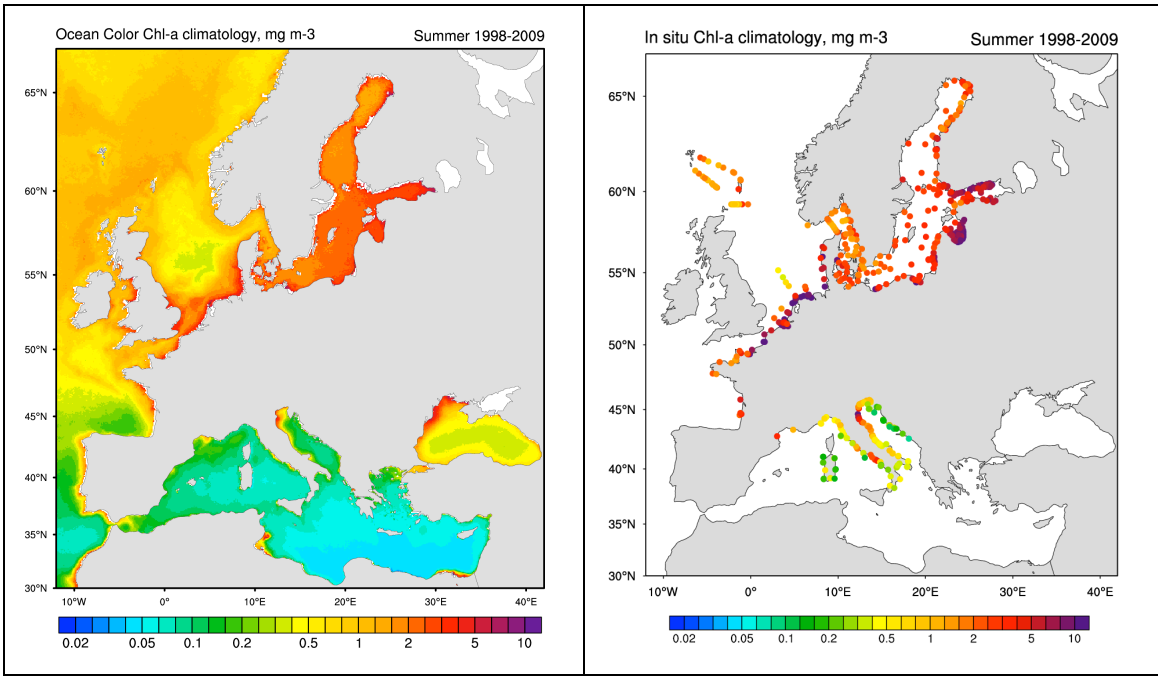

OSD

9, 1481-1518, 2012

Ocean-colour Chl a trends in European

Seas

G. Coppini et al.

\section{Title Page}

Abstract

Introduction

Conclusions

References

Tables

Figures

14

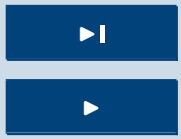

Back

Close

Fig. 1. Summer (May-Sept) mean Chl a concentration in European seas for the period 1998-2009 from the MyOcean ocean-colour global dataset (left panel) and the Eionet in-situ dataset (right panel).

Printer-friendly Version

Interactive Discussion 

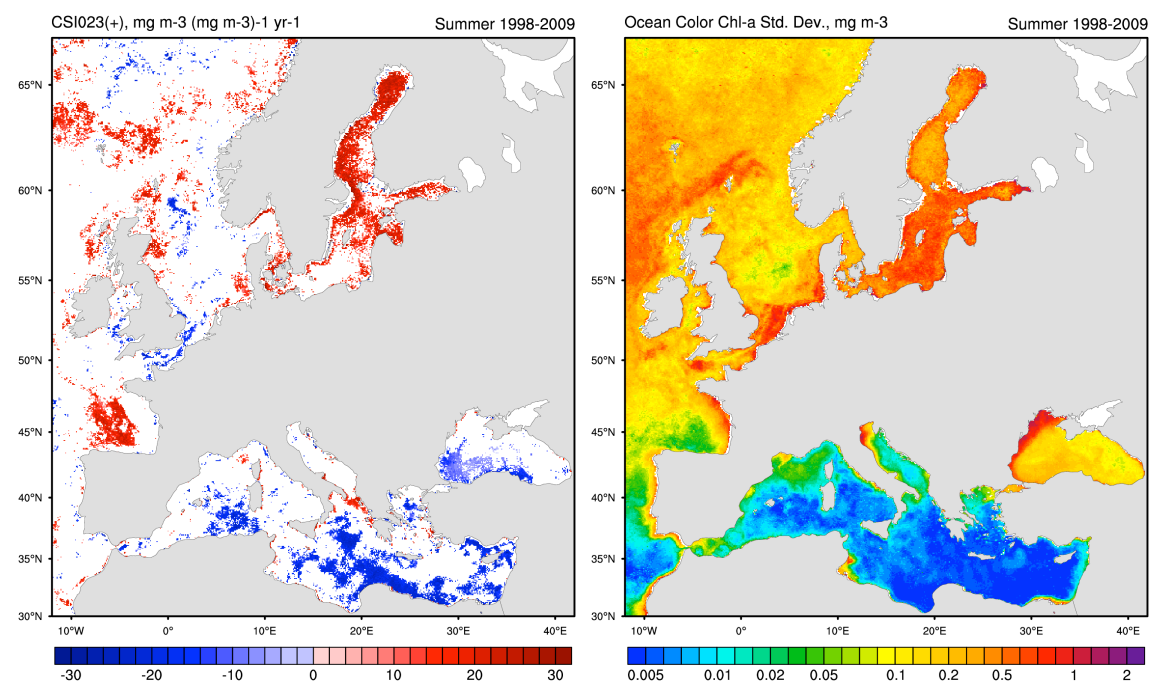

Fig. 2. CSI023 (+) pan-European trend indicator values $\left(\mathrm{mg} \mathrm{m}^{-3}\left(\mathrm{mg} \mathrm{m}^{-3}\right)^{-1} \mathrm{yr}^{-1}\right)$ (left panel) for the period 1998-2009. White areas indicate values that are not statistically significant. Chl a standard deviation $\left(\mathrm{mg} \mathrm{m}^{-3}\right)$ (right panel) for the period 1998-2009.

OSD

$9,1481-1518,2012$

Ocean-colour Chl a trends in European

Seas

G. Coppini et al.

\section{Title Page}

Abstract

Introduction

Conclusions

References

Tables

Figures

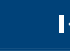

14

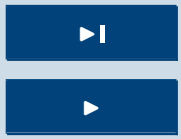

Back

Close

\section{Full Screen / Esc}

Printer-friendly Version

Interactive Discussion 


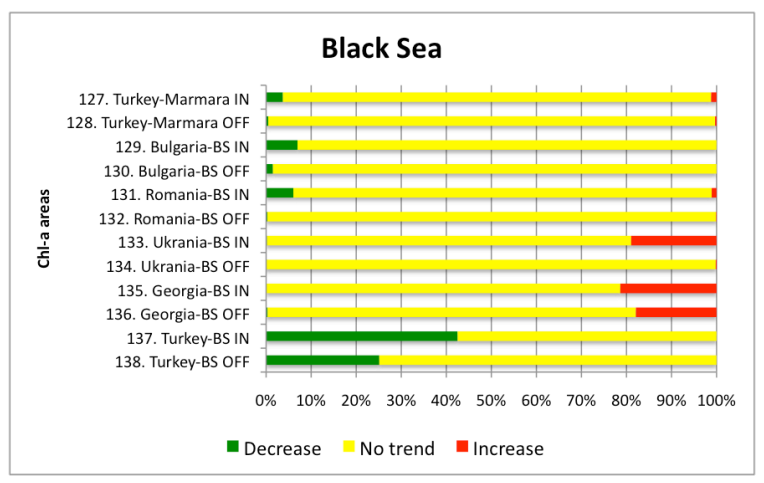

OSD

9, 1481-1518, 2012

a)

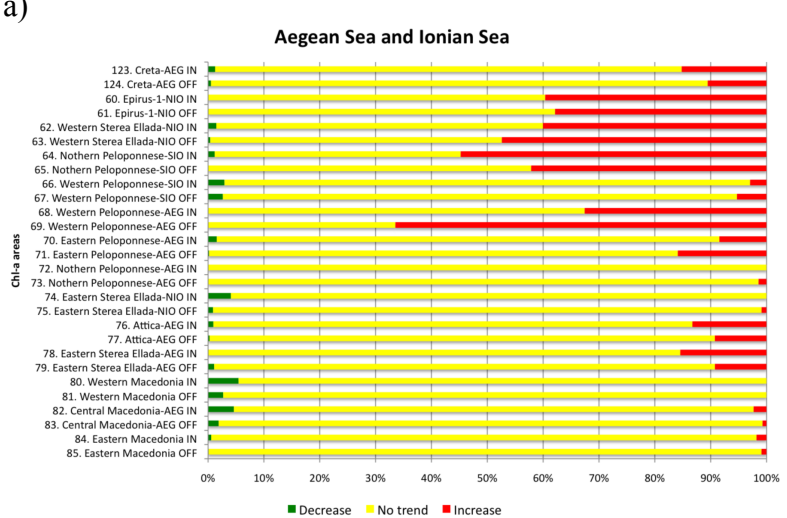

b)

\section{Ocean-colour $\mathrm{Chl}$ a trends in European \\ Seas}

G. Coppini et al.

\section{Title Page}

Abstract

Introduction

Conclusions

References

Tables

Figures

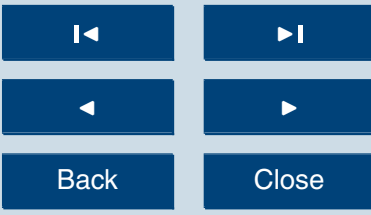

Full Screen / Esc

Fig. 3. (a) and (b). CSI023 (+) Chl a area trend indicators in the Black Sea (a) and Aegean and Ionian Seas (b) for the period 1998-2007. For each Chl a area the red bars indicate the percentage of grid points with significant increasing trends, the green bars indicate the percentage of grid points with decreasing significant trends and the yellow bars indicate the percentage of grid points without significant trend.

Interactive Discussion 


\section{European Seas}

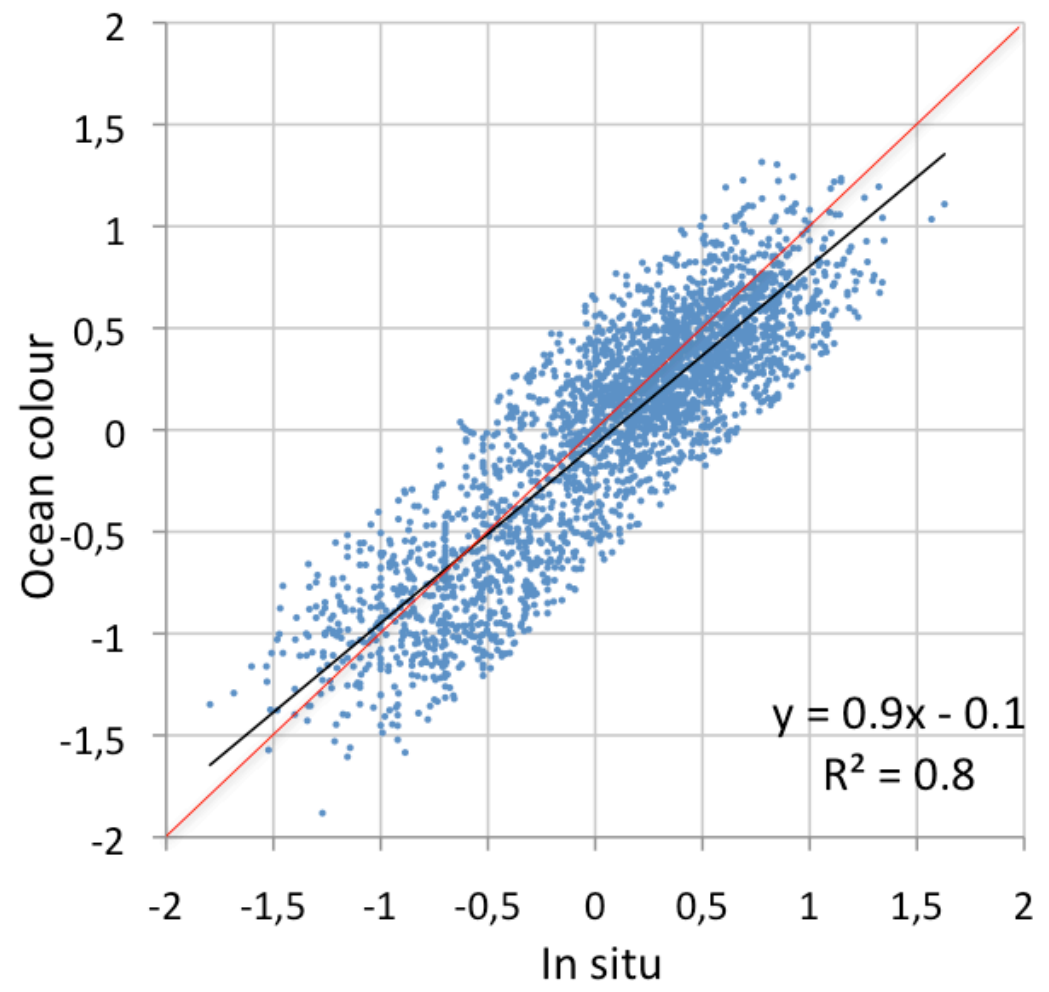

Fig. 4. Summer Chl $a$ in-situ concentration and the ocean-colour Global Ocean GSM - MyOcean Chl a concentration for all selected stations in the European seas (Log10 $\mathrm{mg} \mathrm{m}^{-3}$ ). The black line is the best linear approximation between ocean colour $(y)$ and in-situ values $(x)$. The reference red line corresponds to the $y=x$ approximation.

\section{OSD}

9, 1481-1518, 2012

Ocean-colour Chl a trends in European

Seas

G. Coppini et al.

\section{Title Page}

\section{Abstract}

Introduction

Conclusions

References

Tables

Figures
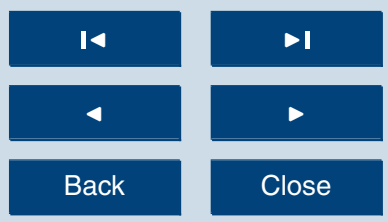

Full Screen / Esc

Printer-friendly Version

Interactive Discussion 


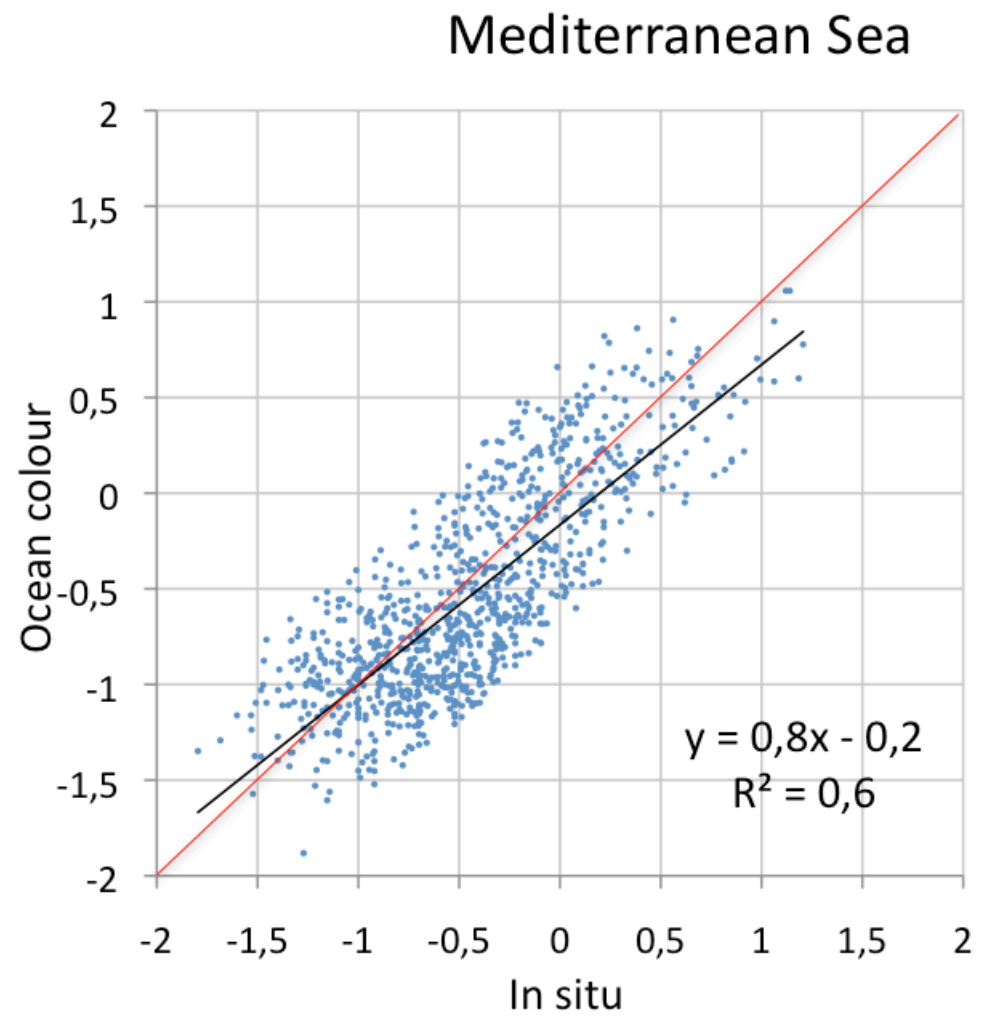

Fig. 5. Summer Chl a in-situ concentration and the ocean-colour Global Ocean GSM - MyOcean Chl a concentration for all selected stations in the Mediterranean Sea (Log10 $\mathrm{mg} \mathrm{m}^{-3}$ ). The black line is the best linear approximation between ocean colour $(y)$ and in-situ values (x). The reference red line corresponds to the $y=x$ approximation.

\section{OSD}

9, 1481-1518, 2012

Ocean-colour $\mathrm{Chl}$ a trends in European Seas

G. Coppini et al.

\section{Title Page}

\section{Abstract}

Introduction

Conclusions

References

Tables

Figures
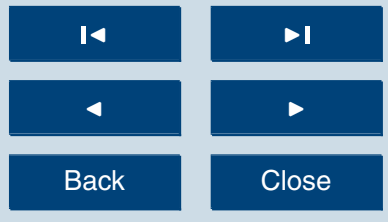

Full Screen / Esc

Printer-friendly Version

Interactive Discussion 


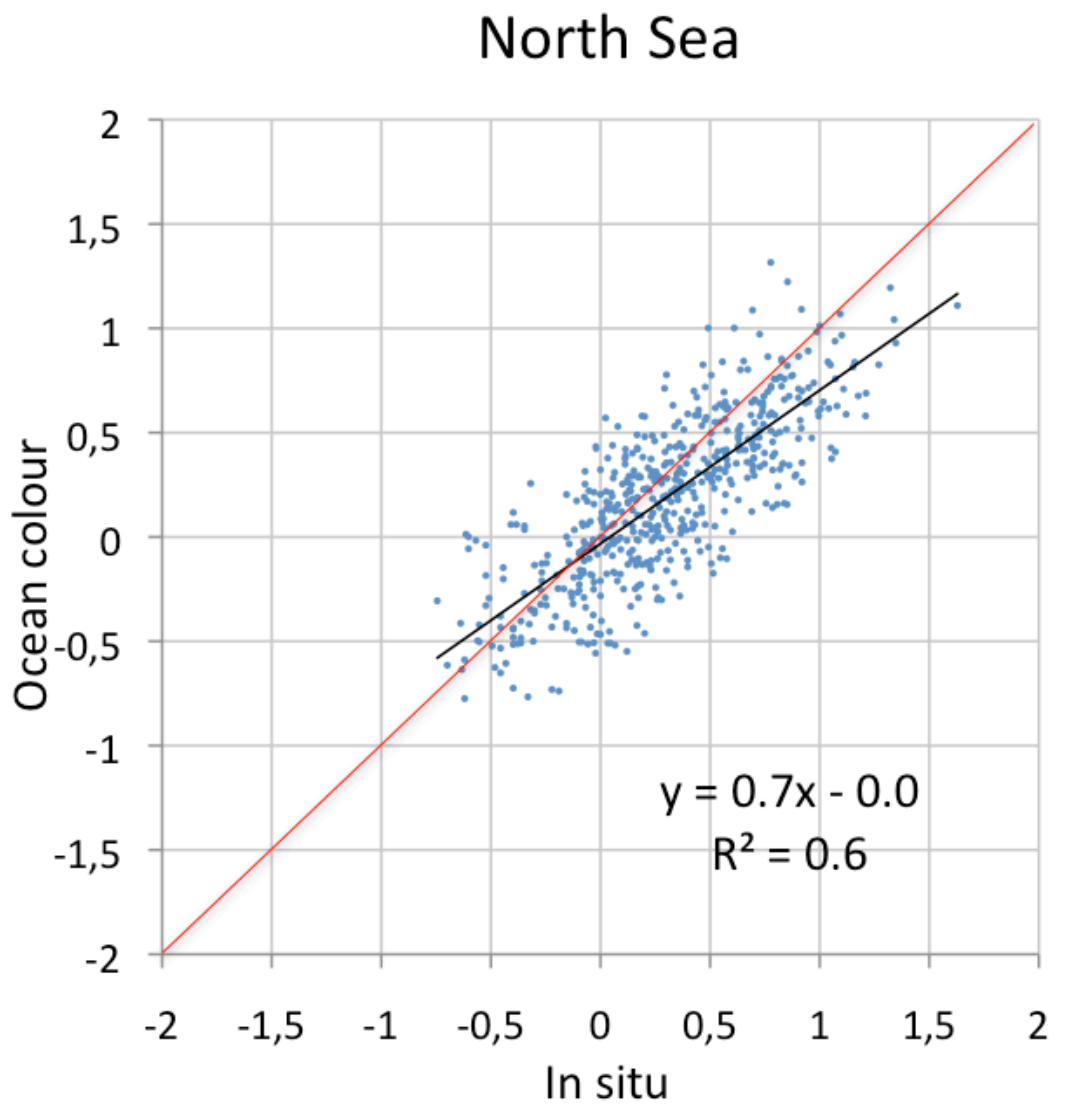

OSD

9, 1481-1518, 2012

Ocean-colour $\mathrm{Chl} \mathrm{a}$ trends in European

Seas

G. Coppini et al.

\section{Title Page}

Abstract

Introduction

Conclusions

References

Tables

Figures

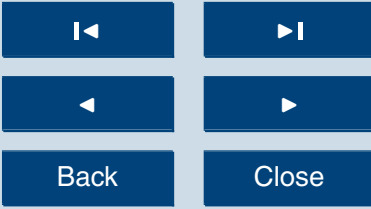

Full Screen / Esc

Fig. 6. Summer Chl a in-situ concentration and the ocean-colour Global Ocean GSM - MyOcean Chl a concentration for all selected stations in the North Sea $\left(\log 10 \mathrm{mg} \mathrm{m}^{-3}\right)$. The black line is the best linear approximation between ocean colour $(y)$ and in-situ values $(x)$. The reference red line corresponds to the $y=x$ approximation.

Printer-friendly Version

Interactive Discussion

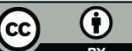




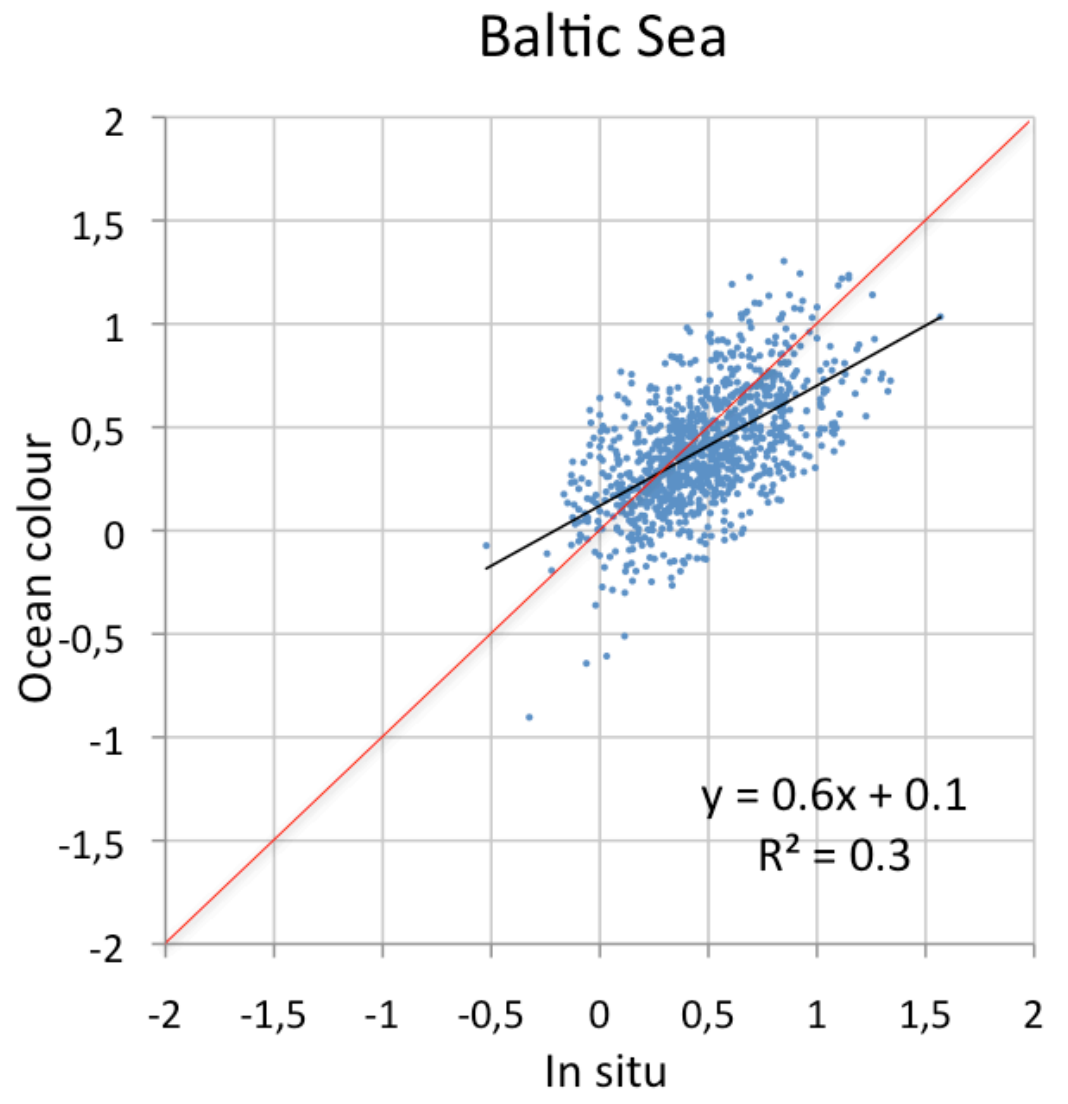

Fig. 7. Summer Chl a in-situ concentration and the ocean-colour Global Ocean GSM - MyOcean Chl a concentration for all selected stations in the Baltic Sea (Log10 $\mathrm{mg} \mathrm{m}^{-3}$ ). The black line is the best linear approximation between ocean colour $(y)$ and in-situ values $(x)$. The reference red line corresponds to the $y=x$ approximation.
OSD

$9,1481-1518,2012$

Ocean-colour Chl a trends in European Seas

G. Coppini et al.

\section{Title Page}

Abstract

Introduction

Conclusions

References

Tables

Figures

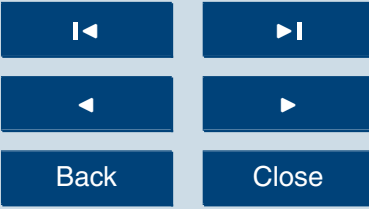

Full Screen / Esc

Printer-friendly Version

Interactive Discussion 


\section{North East Atlantic}

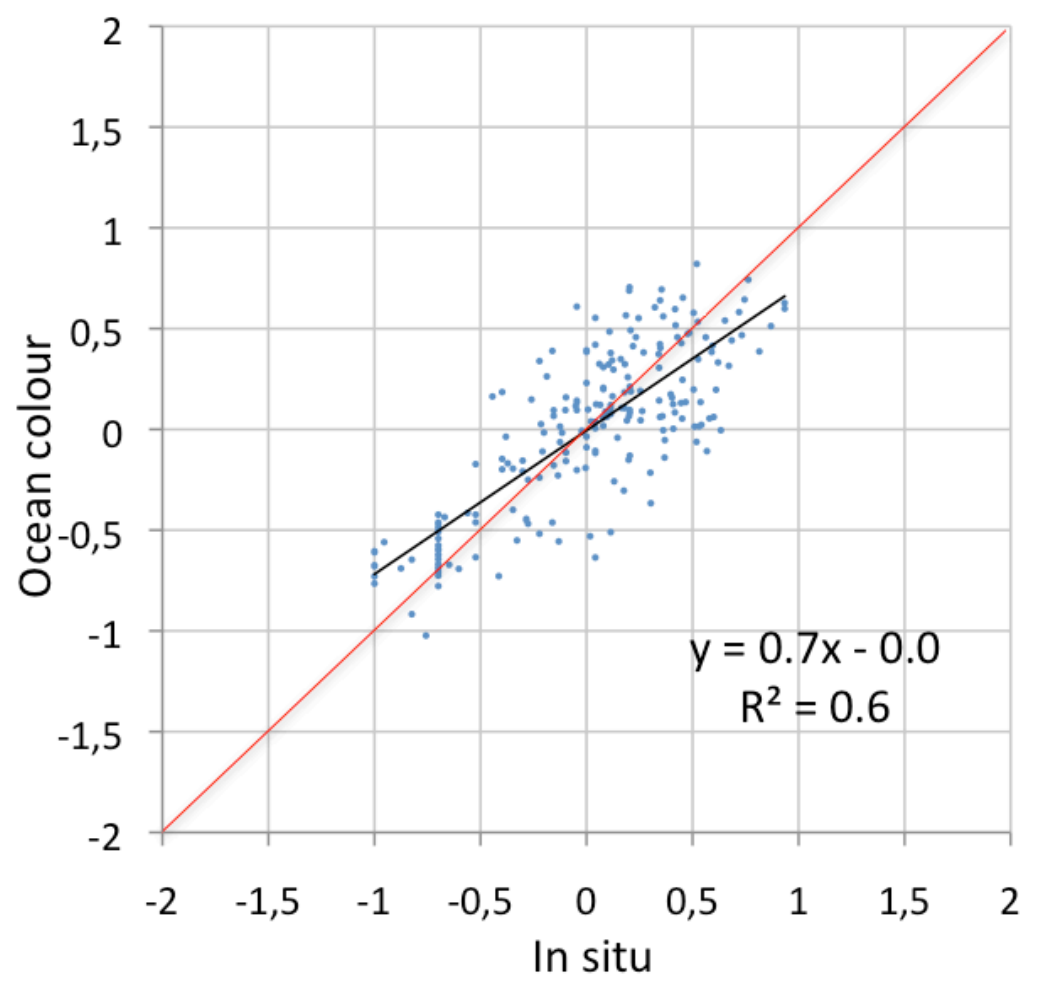

Fig. 8. Summer Chl a in-situ concentration and the ocean-colour Global Ocean GSM - MyOcean Chl a concentration for all selected stations in the North-East Atlantic $\left(\log 10 \mathrm{mg} \mathrm{m}^{-3}\right)$. The black line is the best linear approximation between ocean colour (y) and in-situ values (x). The reference red line corresponds to the $y=x$ approximation.

\section{OSD}

9, 1481-1518, 2012

Ocean-colour Chl a trends in European

Seas

G. Coppini et al.

\section{Title Page}

Abstract

Introduction

Conclusions

References

Tables

Figures

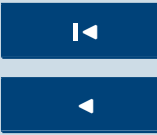

Back

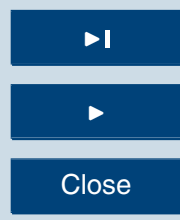

Full Screen / Esc

Printer-friendly Version

Interactive Discussion 


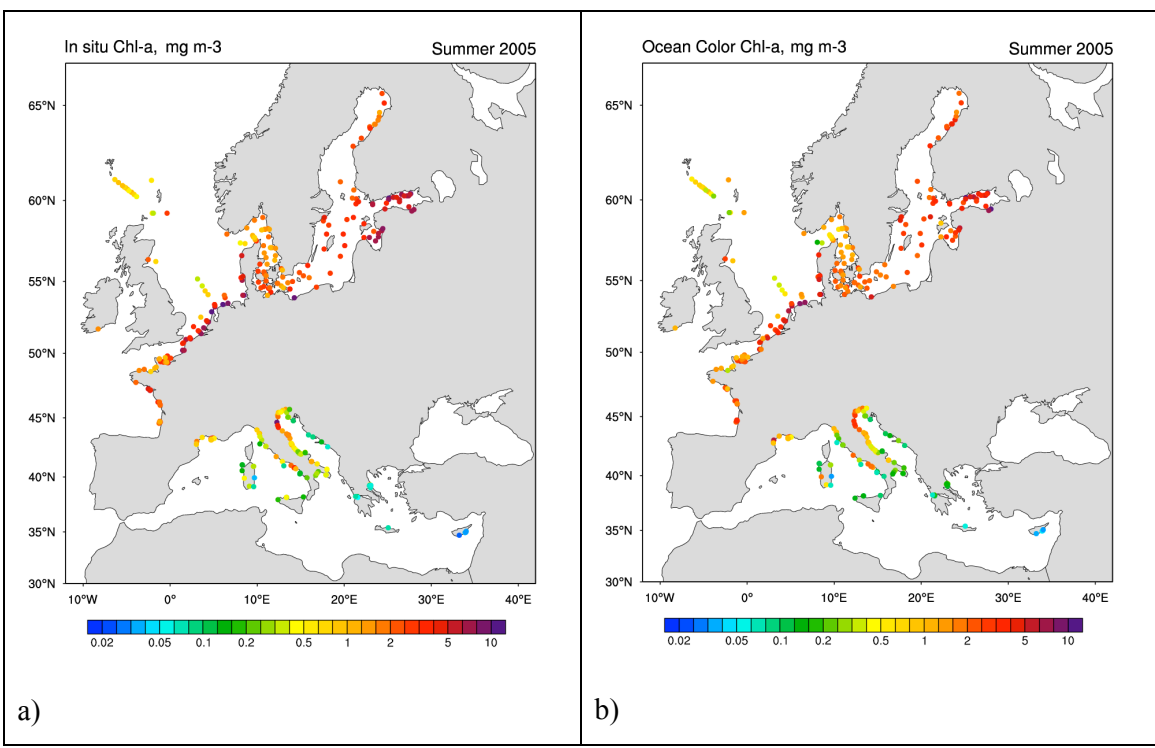

Fig. 9. Chl a concentration $\left(\mathrm{mg} \mathrm{m}^{-3}\right)$ as estimated by ocean colour (a) and in-situ data (b) for the 2005 summer period.

\section{OSD}

$9,1481-1518,2012$

Ocean-colour Chl a trends in European Seas

G. Coppini et al.

\section{Title Page}

\section{Abstract}

Introduction

Conclusions

References

Tables

Figures

14

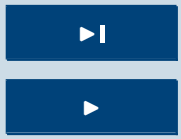

Back

Close

\section{Full Screen / Esc}

Printer-friendly Version

Interactive Discussion 


\section{European Seas}

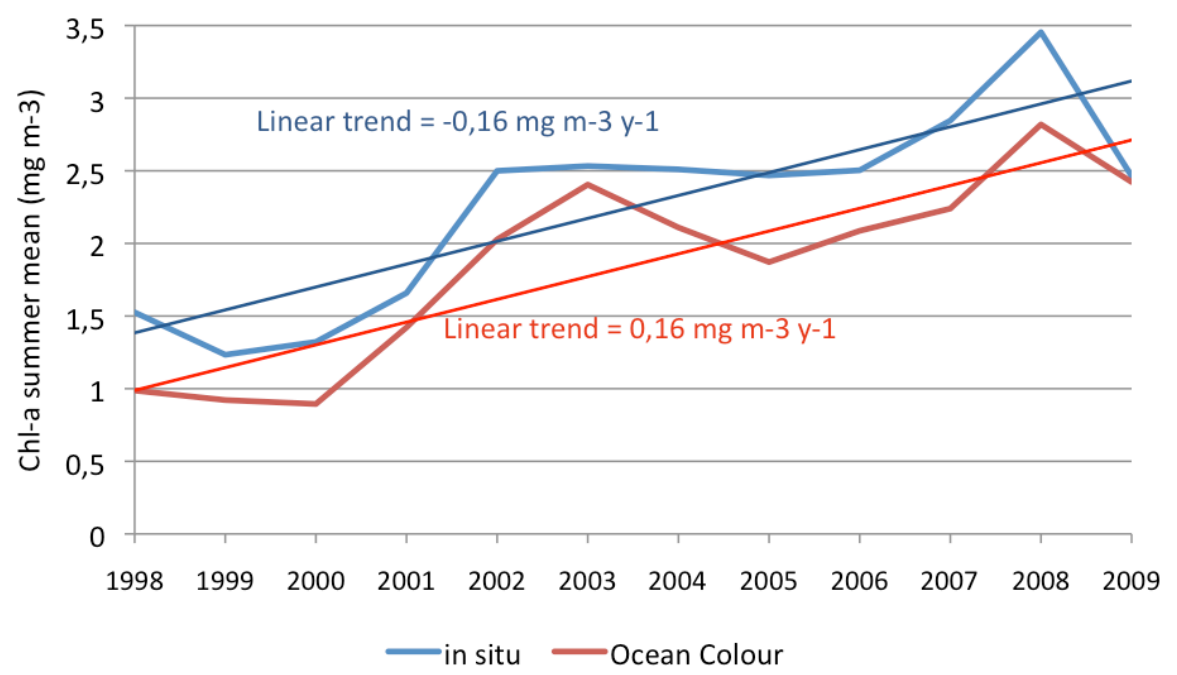

Fig. 10. European seas summer annual means and regression lines for both in-situ (blue) and ocean-colour Global Ocean GSM - MyOcean (red) data.

Ocean-colour Chl a trends in European Seas

G. Coppini et al.

Title Page

Abstract

Conclusions

Tables

14

4

Back

Introduction

References

Figures

Full Screen / Esc

Printer-friendly Version

Interactive Discussion

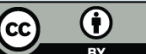




\section{Mediterranean Sea}

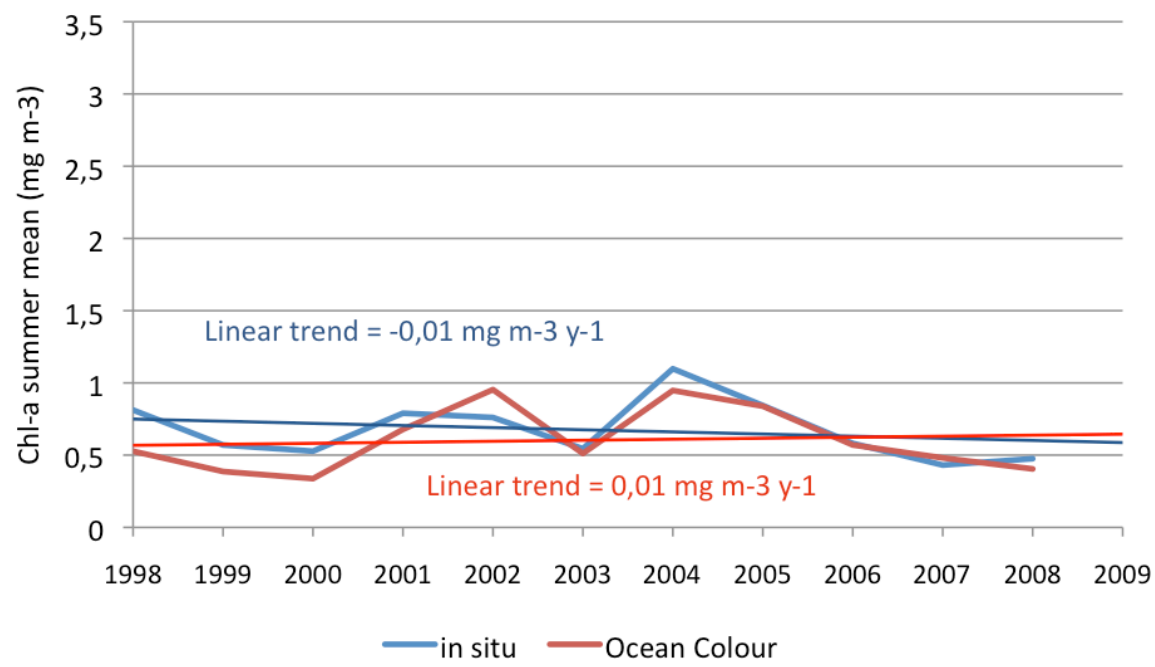

Fig. 11. Mediterranean Sea summer annual means and regression lines for both in-situ (blue) and ocean-colour Global Ocean GSM - MyOcean (red) data.

\section{OSD}

$9,1481-1518,2012$

Ocean-colour Chl a trends in European Seas

G. Coppini et al.

\section{Title Page}

Abstract

Introduction

Conclusions

References

Tables

Figures

14

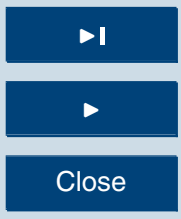

Back

Close

Full Screen / Esc

Printer-friendly Version

Interactive Discussion

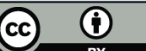




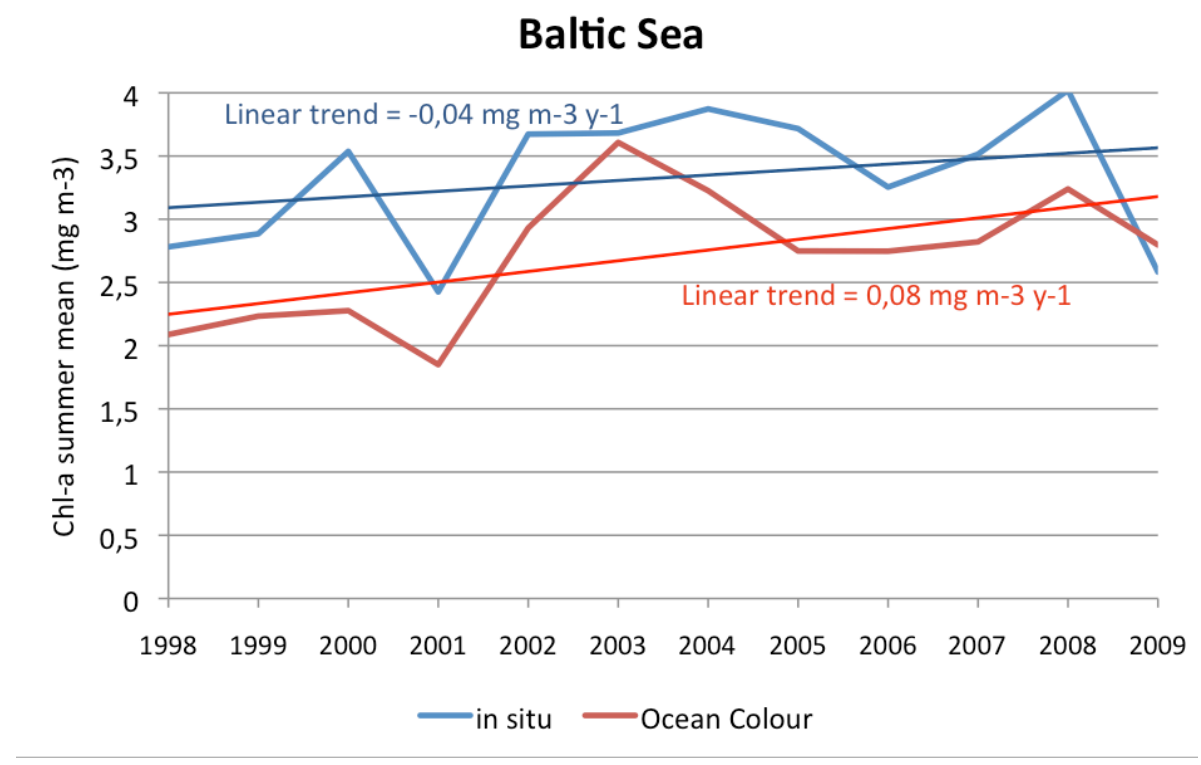

Fig. 12. Baltic Sea summer annual means and regression lines for both in-situ (blue) and ocean-colour Global Ocean GSM - MyOcean (red) data.

\section{OSD}

$9,1481-1518,2012$

Ocean-colour Chl a trends in European Seas

G. Coppini et al.

\section{Title Page}

Abstract

Introduction

Conclusions

References

Tables

Figures

14

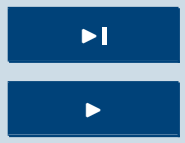

Back

Close

Full Screen / Esc

Printer-friendly Version

Interactive Discussion 


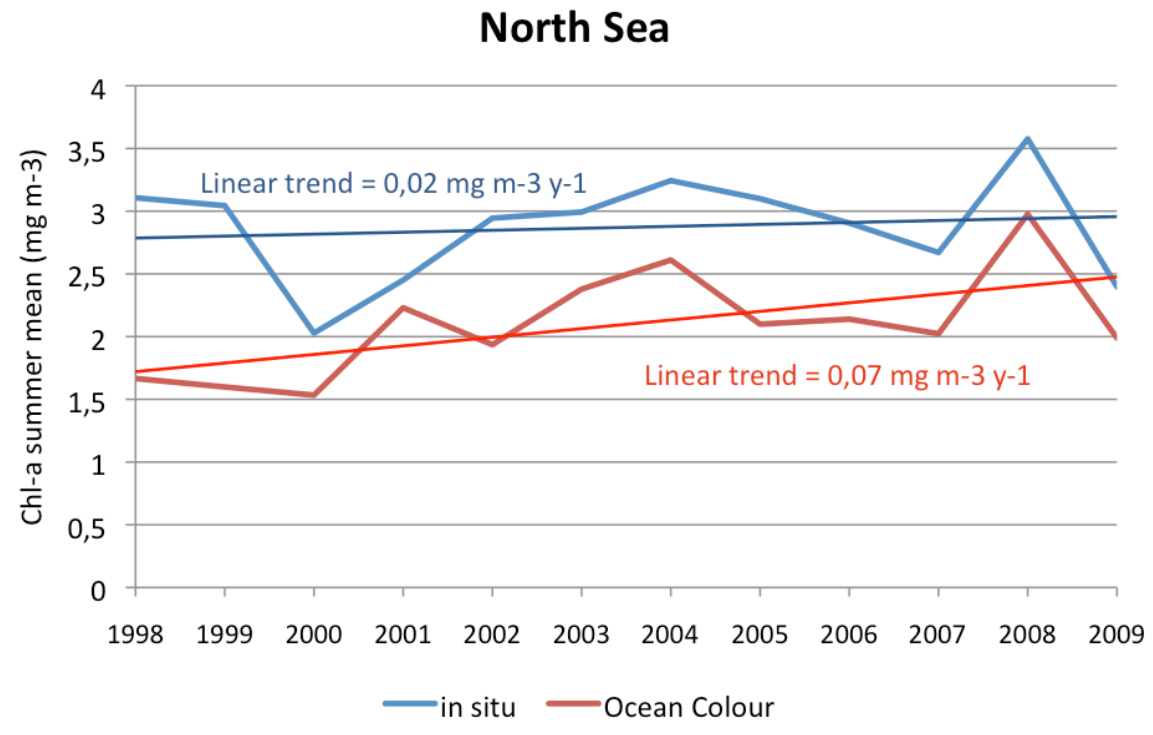

Fig. 13. North Sea summer annual means and regression lines for both in-situ (blue) and ocean-colour Global Ocean GSM - MyOcean (red) data.

Ocean-colour Chl a trends in European Seas

G. Coppini et al.

Title Page

\section{Abstract}

Conclusions

Tables

14

4

Back

Introduction

References

Figures

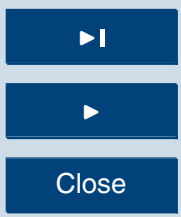

Full Screen / Esc

Printer-friendly Version

Interactive Discussion 


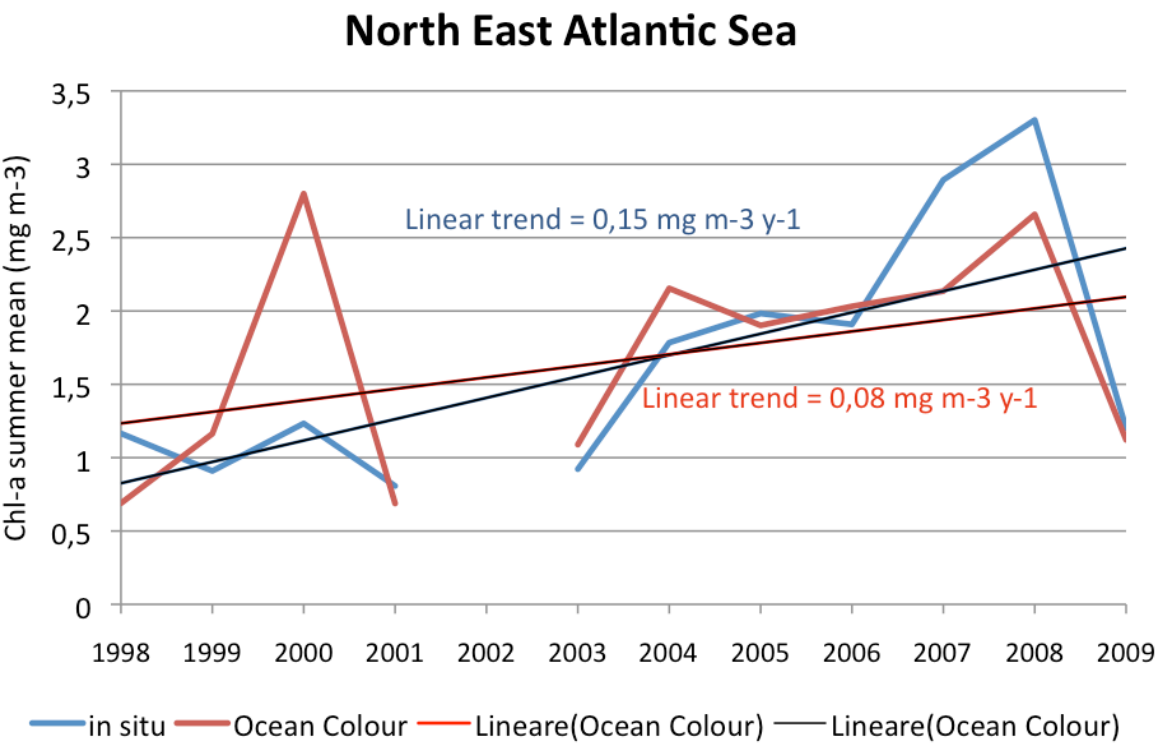

Fig. 14. North-East Atlantic summer annual means and regression lines for both in-situ (blue) and ocean-colour Global Ocean GSM - MyOcean (red) data.

Ocean-colour Chl a trends in European Seas

G. Coppini et al.

\section{Title Page}

Abstract

Introduction

Conclusions

References

Tables

Figures

14

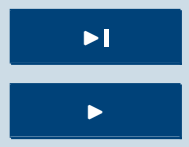

Back

Close

Full Screen / Esc

Printer-friendly Version

Interactive Discussion 


\section{Mediterranean Sea}

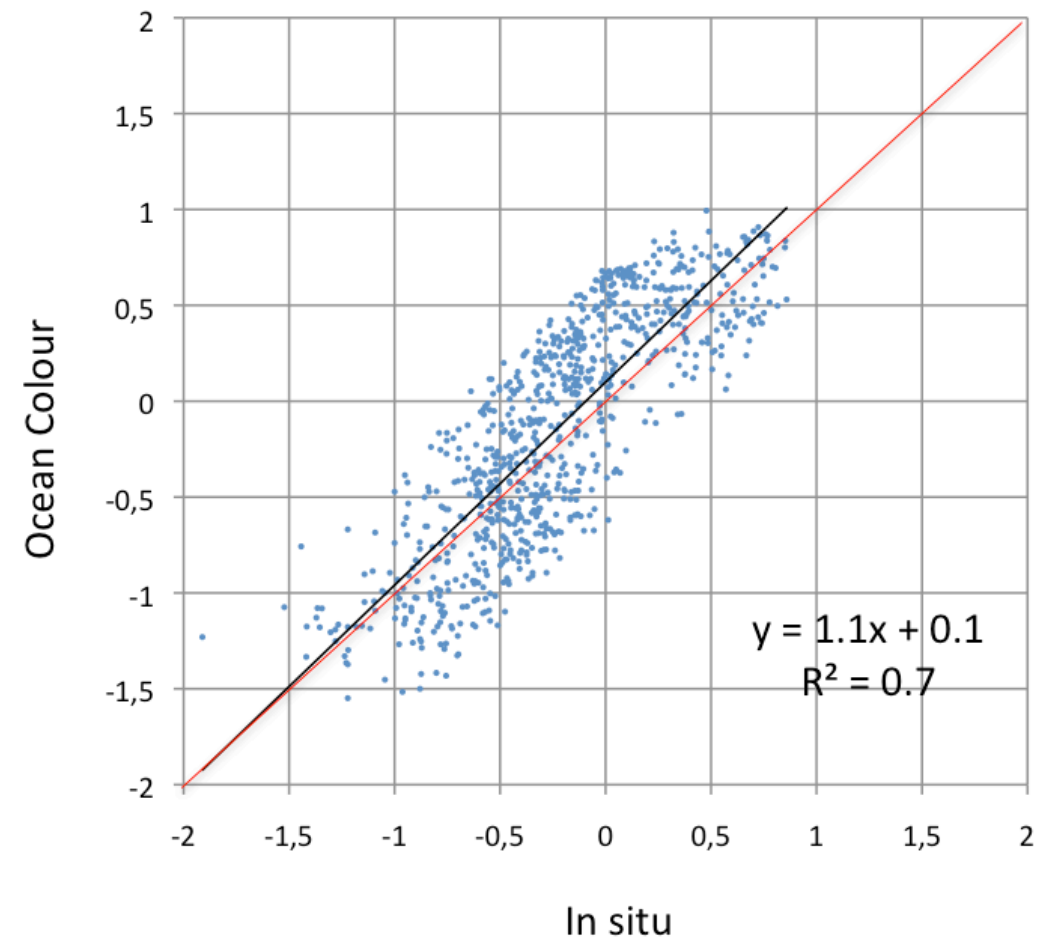

Fig. 15. Summer log10 $\mathrm{Chl} a$ in-situ concentration (x axis) compared with the ocean-colour Med Regional SeaWiFS - MyOcean and CNR log10 Chl a concentration (y axis) for all defined $\mathrm{Chl}-\mathrm{a}$ areas. Log10 Chl a values are expressed in $\mathrm{mg} \mathrm{m}^{-3}$.

\section{OSD}

9, 1481-1518, 2012

Ocean-colour Chl a trends in European Seas

G. Coppini et al.

\section{Title Page}

Abstract

Introduction

Conclusions

References

Tables

Figures

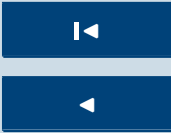

Back

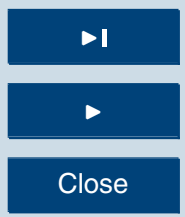

Full Screen / Esc

Printer-friendly Version

Interactive Discussion

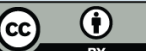

